\title{
Atrakcyjność hoteli w percepcji nabywców usług turystycznych na przykładzie Turcji
}

DOI: 10.19195/2083-7763.9.19

\section{Wstęp}

Zachowania konsumentów mogą dotyczyć nabywania produktów i usług. W artykule skoncentrowano się na tym drugim zagadnieniu, odnosząc zachowania nabywców do usług oferowanych przez touroperatorów - wyjazdów zagranicznych i pobytów w obiektach hotelowych. Wraz z transformacją systemową zwiększyły się możliwości podróżowania Polaków za granicę. W dużej części wyjazdów wypoczynkowych i turystycznych pośredniczą biura podróży. Z perspektywy konsumenta świadczą one całościową usługę — oferują dowóz do wybranego miejsca, wynikające z przedstawionej oferty opcje zakwaterowania i wyżywienia, proponują także usługi dodatkowe (ubezpieczenia, dodatkowe wycieczki na miejscu, wybór miejsca w środku transportu itp.). Ich oferty prezentowane są między innymi w sieci, więc nabywcy mają możliwość zapoznania się z szeregiem propozycji i podjęcia decyzji. Realia zakupionej oferty mogą niekiedy odbiegać od początkowych oczekiwań konsumentów, a jej wybrane elementy mogą być dla nich istotniejsze niż inne. $\mathrm{W}$ niniejszym artykule, posługując się przykładem Turcji, przyjrzano się oczekiwaniom i realiom pobytu w obiektach hotelowych o wysokim standardzie. Turystyka stanowi istotny element PKB kraju, dodatkowo od wielu lat Turcja jest atrakcyjna dla turystów z Polski. Zainteresowanie wyjazdami turystycznymi do tego kraju spadło w latach 2014-2016 w związku z problemami wewnętrznymi oraz zagrożeniem terrorystycznym. W drugiej części 2017 roku turyści powoli zaczęli „wracać”, a kończący się rok 2018 może być z perspektywy Turcji uznany za bardzo dobry pod względem realizacji usług turystycznych. Niniejszy artykuł składa się zasadniczo z trzech zagadnień. 
Po pierwsze - uznając, że turystyka jest ważnym elementem spędzania wolnego czasu we współczesnych społeczeństwach i daje jednostkom możliwość realizacji wielu potrzeb - podjęto próbę określenia zachowań Polaków w tym wymiarze. Po drugie - podjęto próbę krótkiej charakterystyki Turcji jako kraju uznającego dochody z turystyki za istotny składnik PKB. Wreszcie, po trzecie - podjęto próbę odpowiedzi na pytanie o to, co dla turystów z Polski jest istotne, gdy wybiorą już kraj, miejsce pobytu i hotel.

Niniejszy artykuł opiera się na różnorodnych danych wtórnych. Są wśród nich statystyki generowane przez rozmaite podmioty, sondaże opinii, wypowiedzi turystów zamieszczone na forum internetowym. W wykorzystanych danych wtórnych jak w soczewce skupiają się wady i zalety badań niereaktywnych. Selektywność statystyk i danych, coroczna realizacja badań przez ośrodek demoskopijny uniemożliwiająca pozyskanie danych z roku 2018, rozmaite sposoby zbierania i pozyskiwania danych pierwotnych przez autorów raportów, niwelują często możliwość określenia trendów. Z drugiej jednak strony egzemplifikują - jak w przypadku terroryzmu - wpływ określonych czynników na zachowania konsumentów. Materiały wytworzone przez uczestników turystyki zorganizowanej mają charakter subiektywny, niekiedy wybiórczy i emocjonalny, kiedy indziej zaś schematyczny. Pozwalają one jednak dowiedzieć się, co dla turystów jest istotne, jakie walory miejsc pobytu przede wszystkim doceniają, co się im podoba, a co powoduje u nich dysonans, czy wręcz niezadowolenie.

\section{Turystyka jako obszar zachowań konsumenckich}

Turystyka jako typ aktywności ludzkiej pojawiła się już wiele wieków temu, między innymi wraz z religijnym pielgrzymowaniem. Ewoluowała, wykształcały i wciąż wykształcają się jej nowe formy. W drugiej połowie XX wieku turystyka nabrała charakteru masowego i zorganizowanego ${ }^{1}$, co spowodowało rozwój zainteresowań naukowych oraz komercyjnych wokół tego zjawiska. Samo umasowienie turystyki w skali społeczeństw mogło stać się realne w wyniku pojawienia się kategorii nazwanej czasem wolnym. Czas stał się jednym z elementów konsumpcjonizmu ${ }^{2}$. Czas ten Lech Milian nazywa „podłożem zasadniczym turystyki”, wskazując na konieczność wystąpienia także innych czynników: chęci wyjazdu, środków finansowych, środków transportu pozwalających szybko przemieszczać się na duże odległości ${ }^{3}$. Z perspektywy nabywców istotne staje się posiadanie

${ }^{1}$ K. Sala, Postmodernistyczne zachowania konsumentów na rynku turystycznym w Polsce, Kraków 2018, s. 62.

2 A. Perchla-Włosik, Współczesny konsumpcjonizm, [w:] Kulturowe determinanty zachowań konsumenckich, red. W. Patrzałek, Wrocław 2004, s. 46.

${ }^{3}$ L. Milian, Socjologia czasu wolnego. Wiedza o czynnościach swobodnie wybieranych, Gdańsk 2010, s. 133. 
„funduszu swobodnej decyzji” i wysoka pozycja podróżowania w indywidualnym rankingu jednostki co do potrzeb/preferencji spędzania wolnego czasu 4 . Rozwój turystyki należy do najbardziej charakterystycznych tendencji współczesnego świata ${ }^{5}$, niemniej istotne jest coś jeszcze. Staje się ona potężną dziedziną gospodarki narodowej ${ }^{6}$, to „olbrzymi międzynarodowy biznes”, który „dociera nawet do najbardziej odległych zakątków świata i przygotowuje się do podboju kosmosu"7.

W literaturze przedmiotu obecne są różne podejścia do definiowania turystyki. W ujęciu zaproponowanym przez Światową Organizację Turystyki (World Tourism Organization -WTO)

turystyka obejmuje ogół czynności osób, które podróżują i przebywają w celach wypoczynkowych, zawodowych lub innych nie dłużej niż rok poza swoim codziennym otoczeniem i rytmem życia z wyłączeniem wyjazdów, których głównym celem jest działalność zarobkowå ${ }^{8}$.

Wyłączenie pobytów zarobkowych z obrębu turystyki kwestionuje Krzysztof Przecławski, wskazując, że osoby opuszczające swe miejsce zamieszkania w tym celu podobnie jak turyści korzystają z miejscowej infrastruktury hotelowej czy komunikacyjnej ${ }^{9}$, co niejako, przynajmniej częściowo, czyni ich turystami. W niniejszym artykule turystyka występuje w tym węższym znaczeniu, które proponuje WTO.

Turystyka - czy to pojmowana jako pewna forma aktywności jednostki, czy też postrzegana jako jeden z istotnych sektorów działalności gospodarczej — dziś jest ważnym przedmiotem zainteresowań zarówno praktyków, jak i teoretyków i badaczy ${ }^{10}$. Zainteresowanie turystyką pojawia się w obrębie rozmaitych nauk ${ }^{11}$, sama turystyka ukazuje się jako zjawisko złożone, interdyscyplinarne oraz wielopłaszczyznowe $^{12}$. W obrębie socjologii podejmowane są różne zagadnienia. Turystyka jest traktowana jako zjawisko społeczno-kulturowe. Istotny okazuje się jej wpływ na mieszkańców terenów, na których występuje to zjawisko, ale także

${ }^{4}$ J. Berbeka, Konsumpcja usług turystyki społecznej - obecnie i w przyszłości, „Konsumpcja i rozwój" 2014, nr 2, s. 39.

5 A. Niemczyk, Zróżnicowanie zachowań konsumentów na rynku turystyki kulturowej, Kraków 2012, s. 9.

${ }^{6}$ J. Kaczmarek, A. Stasiak, B. Włodarczyk, Produkt turystyczny: pomysł, organizacja, zarządzanie, Warszawa 2005, s. 9.

7 E. Cohen, Zmieniające się oblicza wspótczesnej turystyki, „Folia Turistica” 25, 2011, nr 2, Wydanie specjalne z okazji 35-lecia Wydziału Turystyki i Rekreacji AWF w Krakowie, „Z warsztatów mistrzów", red. W. Alejziak, s. 14.

8 Cyt. za: L. Milian, op. cit., s. 137-138.

9 K. Przecławski, Człowiek a turysta. Zarys socjologii turystyki, Kraków 1996, cyt. za: L. Milian, op. cit., s. 138-139.

10 W. Alejziak, Globalna polityka turystyczna - utopia, alternatywa czy konieczność?, „Folia Turistica" 25, 2011, nr 2, s. 344.

11 W.J. Cymański, Czas wolny, turystyka i rekreacja w perspektywie socjologicznej, Kraków 2017, s. 181.

12 K. Sala, op. cit., s. 8. 
sami turyści czy też organizatorzy usług turystycznych. W tym wymiarze analizowane są zarówno uwarunkowania, jak i skutki społeczne turystyki ${ }^{13}$. Socjologia turystyki, jako subdyscyplina socjologii, zajmowałaby się więc określonymi zbiorowościami, poszukując na przykład związków między ich cechami (narodowość, wiek, wykształcenie, płeć) a wyborem określonych form turystyki ${ }^{14}$. Jedną z funkcji, które niesie w przemianach życia społecznego turystyka, jest funkcja ekonomiczna. Jako dziedzina gospodarki ma ona związek z rynkiem turystycznym, co de facto sprowadza się do aktów kupna i sprzedaży. „W efekcie zaistnienia w skali masowej rynku turystycznego, współczesny turysta, jeśli pragnie odbyć konkretną, wybraną podróż turystyczną, musi skorzystać z pomocy przedsiębiorcy lub przedsiębiorców ulokowanych na rynku turystycznym"15. Oczywiście współcześnie istnieje wiele rozwiązań charakterystycznych dla społeczeństw postmaterialistycznych, w których oprócz zorganizowanych i masowych usług pojawiają się nowe formy (na przykład turystyka przeżyć ekstremalnych, pobyty na terenach militarnych, turystyka kulinarna). W niniejszym ujęciu jako obszar zainteresowań jawi się jednak właśnie owa „tradycyjna”, masowa turystyka, zapośredniczona przez konkretnych touroperatorów.

Konsumpcja turystyczna jest interpretowana jako wiele aktywności związanych z podróżowaniem i zaspokajaniem potrzeb osób podróżujących, które są realizowane $\mathrm{w}$ ramach szeroko rozumianych produktów turystycznych ${ }^{16}$. Turyści to immanentny element rynku turystycznego, weryfikują oni przedsięwzięcia rynkowe przedsiębiorstw tworzących produkty turystyczne. Znajomość ich zachowań decyduje o sukcesie lub porażce ${ }^{17}$. Zachowania konsumentów na rynku usług turystycznych definiuje się jako

ogół działań, czynności podejmowanych przez konsumentów o określonych cechach psychofizycznych, związanych z dokonywaniem wyborów w procesie zaspokajania potrzeb turystycznych w określonych warunkach ekonomicznych, społecznych, demograficznych, geograficznych ${ }^{18}$.

Mówimy tu zatem o procesie, który wychodząc z motywu podróżowania, prowadzi do zaspokojenia potrzeby turystycznej ${ }^{19}$. Odczuwanie potrzeby, jej ważność wśród innych, preferencje oraz zaspokojenie są uzależnione od sytuacji ekonomicznej potencjalnego konsumenta oraz jego charakterystyki socjodemograficznej,

13 W.J. Cymański, op. cit., s. 194.

14 L. Milian, op. cit., s. 140.

15 Ibidem, s. 149.

16 A. Wolska, Trendy w konsumpcji turystycznej na przykładzie mieszkańców Majorki, „Prace Naukowe Uniwersytetu Ekonomicznego we Wrocławiu” 2015, nr 379, s. 357-358.

17 K. Sala, op. cit., s. 58.

18 Ibidem.

19 J. Berbeka, Zachowania polskich konsumentów na rynku usług turystycznych, [w:] Zachowania konsumentów na rynku dóbr i usług, red. I. Ozimek, Warszawa 2010, s. 84-102. 
ale także cen tych usług i innych czynników ${ }^{20}$. Na korzystanie z usług turystycznych wpływa wiele czynników. Są to czynniki ekonomiczne (głównie dochody klientów i ich wysokość w stosunku do ceny potencjalnej usługi turystycznej, kursy wymiany walut), geograficzne (położenie danego kraju, warunki klimatyczne, temperatury i opady, wreszcie samo usytuowanie hotelu względem tego, co turysta uznaje za atrakcyjne), polityczne (stabilność polityczna kraju, zamachy terrorystyczne), społeczne (charakterystyki socjodemograficzne, takie jak między innymi wielkość rodziny, wiek, płeć, wykształcenie turystów, zainteresowania, preferencja spędzania czasu wolnego) oraz psychologiczne (motywy, doznania, przeżycia) ${ }^{21}$. Spędzanie czasu wolnego staje się coraz częściej przejawem własnej tożsamości w związku z rosnącym znaczeniem konsumpcji jako stylu życia ${ }^{22}$.

\section{Zagraniczne wyjazdy wypoczynkowe Polaków}

Turystyka masowa rozwija się w krajach Zachodu od czasu zakończenia drugiej wojny światowej. W krajach za żelazną kurtyną było inaczej.

Zamknięte granice, traktowanie paszportu jako przywileju, niewymienialność krajowych walut, czarny rynek dolara, zakaz wwozu zachodniej prasy i książek, znacznie niższy poziom życia, niewielka liczba autostrad i połączeń lotniczych, monopol państwa w przemyśle (także turystycznym) to najważniejsze z wielu czynników, które powodowały, że turystyka zagraniczna była $\mathrm{w}$ tych krajach zjawiskiem marginalnym i wyraźnie różniącym się od turystyki na Zachodzie ${ }^{23}$.

Umasowienie podróży Polaków nastąpiło w wyniku zmian transformacyjnych przełomu lat 80. i 90. XX wieku, co wynikało z demokratyzacji i otwarcia na świat krajów ościennych, ale także umożliwienia obywatelom trzymania paszportów w domach oraz urealnienia kursu dolara ${ }^{24}$. Kolejnym etapem było wejście Polski do Unii Europejskiej (1 maja 2014) i zniesienie południowej i zachodniej granicy wraz z przystąpieniem do układu z Schengen (21 grudnia 2007) ${ }^{25}$.

W 2013 roku największy odsetek Polaków, którzy deklarowali wypoczywanie lub uprawianie turystyki za granicą, wskazał Niemcy jako kraj pobytu (19\%).

20 J. Sikora, Teoretyczno-empiryczne aspekty związków potrzeb, popytu i konsumpcji w turystyce, „Zeszyty Naukowe Uniwersytetu Szczecińskiego. Ekonomiczne Problemy Usług” 2012, nr 82, s. $132-133$.

21 Por. V.T.C. Middelton, Marketing w turystce, Warszawa 1996, s. 37n.

22 A. Perchla-Włosik, J. Wardzała, Wybrane zachowania młodzieży realizowane $w$ sferze konsumpcji w świetle badań własnych, [w:] Wspótczesna teoria i praktyka badań społecznych i humanistycznych. Ksiegga Jubileuszowa Wydziału Nauk Społecznych, red. J. Juchnowski, R. Wiszniowski, Toruń 2013, s.704-720.

${ }^{23}$ K. Podemski, Polski turysta za granica. Od stalinizmu do Schengen $i$ Wizz Air, „Folia Turistica” 25, 2011, nr 2, s. 236.

24 Ibidem, s. 246.

25 Ibidem, s. 247. 
Na drugim miejscu znalazły się takie kraje, jak: Chorwacja, Czechy, Włochy oraz Turcja (po 10\% wskazań). Kolejne pozycje zajęła Hiszpania (9\%) i Francja (8\%) ${ }^{26}$.

Rok później (2014) Niemcy ponownie stały się krajem najczęściej odwiedzanym w czasie wyjazdów wypoczynkowych i turystycznych (22\%). Na kolejnych pozycjach znalazły się: Chorwacja (14\%), Czechy (13\%) i Hiszpania (9\%). Na dalszej pozycji - za kolejnymi krajami europejskimi - umiejscowiła się Turcja $(7 \%)^{27}$.

W 2015 roku Niemcy po raz kolejny były najczęściej wybieranym krajem podróży (15\%), niemniej taki sam odsetek badanych wskazywał Włochy jako cel pobytu wypoczynkowego lub turystyki. Na kolejnych miejscach znalazły się Grecja i Wielka Brytania (po 11\% wskazań), Hiszpania (10\%), Chorwacja (9\%), Austria (8\%), Czechy i Słowacja (po 7\%) oraz Turcja $(6 \%)^{28}$.

W kolejnym roku (2016) Niemcy sytuowały się po raz czwarty na szczycie rankingu wyjazdów zagranicznych Polaków w celach turystycznych i wypoczynkowych (14\%). Kolejne kraje to: Grecja (13\%), Chorwacja (12\%) i Włochy oraz Hiszpania (po 11\%). Do Turcji wyjeżdżało w tym roku jedynie 3\% badanych ${ }^{29}$, acz nadal był to kraj wybierany najczęściej w porównaniu z krajami oferującymi podobne usługi, pozostającymi w podobnym przedziale cenowym usługi i usytuowanymi poza kontynentem europejskim (w przypadku Turcji zaledwie 3\% kraju - Tracja - leży na terenie Europy ${ }^{30}$ ).

W 2017 roku liderem wśród wyjazdów zagranicznych Polaków była Hiszpania (17\%), kolejne dwa kierunki to Chorwacja (13\%) i Grecja oraz Wielka Brytania $(\text { po } 12 \%)^{31}$. Kolejne pozycje zajmowały Włochy (11\%) i Niemcy (10\%). Dla turystyki Turcji ten rok był nader niekorzystny, gdyż tylko $1 \%$ badanych deklarował pobyt w tym kraju. Po raz pierwszy Turcja jako kraj leżący w dużej mierze poza kontynentem europejskim została wyprzedzona przez atrakcyjniejszy dla turystów z Polski Egipt (4\%).

Warto w tym miejscu wskazać, że powyższe wyniki badań dotyczą wyjazdów co najmniej dwudniowych, stąd też w przypadku krajów położonych stosunkowo blisko Polski mogły być to tak zwane wyjazdy weekendowe realizowane środkami komunikacji publicznej, ale także własnym samochodem. Część tych wyjazdów

${ }^{26}$ Wyjazdy wypoczynkowe Polaków w 2013 roku i plany na rok 2014, „Komunikat z Badań CBOS" nr 25/2014, Warszawa, luty 2014.

27 Wyjazdy wypoczynkowe Polaków w 2014 roku i plany na rok 2015, „Komunikat z Badań CBOS" nr 16/2015, Warszawa, luty 2015.

28 Wyjazdy wypoczynkowe Polaków w 2015 roku i plany na rok 2016, „Komunikat z Badań CBOS" nr 21/2016, Warszawa, luty 2016.

29 Wyjazdy wypoczynkowe Polaków w 2016 roku i plany na rok 2017, „Komunikat z Badań CBOS" nr 24/2017, Warszawa, luty 2017.

30 Położenie i warunki naturalne Turcji, 2.12.2016, http://www.wirtualnaturcja.pl/turcja-geografia/polozenie-i-warunki-naturalne-turcji.html (dostęp: 15.09.2018).

31 Wyjazdy wypoczynkowe Polaków w 2017 roku i plany na rok 2018, „Komunikat z Badań CBOS” nr 28/2018, Warszawa, luty 2018. 
— w przypadku Niemiec, czy Francji - mogła obejmować także wizyty czy zakwaterowanie u rodziny. Możemy więc założyć, że w przypadku sąsiadów Polski, ale także innych państw Europy, mieliśmy do czynienia z wyjazdami niezapośredniczonymi przez touroperatorów, względnie z sytuacjami, kiedy turysta nie wybierał usługi całościowej (rezerwacja hotelu lub noclegu i dojazd własny).

\section{Turcja: polityka i/a turystyka}

Turcja jest krajem atrakcyjnym dla turystów pod wieloma względami ${ }^{32}$. Kraj usytuowany jest na dwóch kontynentach (europejskim i azjatyckim), ma klimat podzwrotnikowy: na wybrzeżu to klimat morski typu śródziemnomorskiego, na wyżynach — kontynentalny suchy. Średnia temperatura w styczniu waha się od 7 stopni Celsjusza na wybrzeżach do 5 stopni w górach. W lipcu, a więc w środku sezonu wyjazdów wakacyjnych, średnia temperatura na terenach nadmorskich, czyli de facto tych, które są dla turystów najatrakcyjniejsze, przekracza 25 stop$\mathrm{ni}^{33}$. Ze względu na walory interesujące turystów, Turcja może być podzielona na siedem regionów. Są to (w kolejności usytuowania od strony europejskiej): wybrzeże Morza Marmara, wybrzeże Morza Egejskiego, wybrzeże Morza Śródziemnego, centralna Anatolia, wybrzeże Morza Czarnego, wschodnia Anatolia oraz południowo-wschodnia Anatolia ${ }^{34}$.

W XXI wieku wraz z pojawieniem się zagrożenia terroryzmem stabilność polityczna kraju i poziom jego bezpieczeństwa wewnętrznego stały się istotne dla zachowań konsumpcyjnych w obszarze usług turystycznych. Turcja - podobnie jak wiele państw atrakcyjnych z perspektywy turystyki masowej dla Europejczyków — jest krajem, w którym dominuje religia islamska. Pod względem politycznym jest krajem, który przeszedł gruntowne przeobrażenia niemal wiek temu. Miały one na celu unowocześnienie i europeizację czy nawet „uzachodnienie” kraju. Proces przeobrażeń państwowości tureckiej był związany z zakończeniem pierwszej wojny światowej oraz wydarzeniami lat 20. XX wieku. Klęska odniesiona w czasie konfliktu światowego doprowadziła do rozpadu imperium oraz powstania nowożytnego państwa ${ }^{35}$. Za ojca narodu i nowożytnego państwa tureckiego uważa się Mustafę Kemala Atatürka ${ }^{36}$. W konstytucji kraju zapisano, że Turcja jest

32 J. Zakrzewska, Potencjał kulturowy Turcji a preferencje turystyczne Polaków i dostępność kulturowej oferty turystycznej, „Turystyka Kulturowa” 2010, nr 12, s. 17.

33 Ibidem, s. 17-18.

34 Ibidem.

${ }^{35}$ K. Bieniek, Ewolucja pozycji ustrojowej władzy wykonawczej w Republice Turcji, „Białostockie Studia Prawnicze" 2016, nr 20/B, https://repozytorium.uwb.edu.pl/jspui/bitstream/11320/4594/1/ BSP_20B_Bieniek.pdf (dostęp: 10.10.2018), s. 397.

36 Więcej na ten temat: K. Wasilewski, Turecki sen o Europie - tożsamość zachodnia i jej wpływ na politykę zagraniczna republiki Turcji, Warszawa 2015, http://wnpism.uw.edu.pl/media/SOBN/ Archiwum\%20WDiNP/Turecki\%20sen\%20o\%20Europie.pdf (dostęp: 10.10.2018). 
republiką, jej językiem urzędowym jest turecki, stolicą miasto w centralnej części kraju - Ankara, a suwerenność bez ograniczeń należy do narodu ${ }^{37}$. Imperium Osmańskie zostało zastąpione państwem tureckim, a monarchię zastąpiła republika, oparta na jedności narodowej ${ }^{38}$.

Oczywiście w okresie dwudziestolecia międzywojennego nie sfinalizowano kwestii zmian ustrojowych, prawnych i politycznych w kraju, niemniej nie są one przedmiotem niniejszego artykułu. Dla podejmowanych w tym miejscu zagadnień istotne są wydarzenia związane z początkiem obecnego stulecia. W 2001 roku została założona Partia Sprawiedliwości i Rozwoju (tur. Adalet ve Kalkınma Partisi, AKP), a jej pierwszym przewodniczącym mianowano Recepa Tayyipa Erdoğana ${ }^{39}$. Rok później (2002) partia uzyskała wysoki wynik wyborczy ${ }^{40}$, który pozwolił jej sprawować samodzielnie władzę. Rozpoczęły się wówczas jej wieloletnie rządy. $\mathrm{W}$ tym czasie dokonało się wiele zmian ustrojowych ${ }^{41}$. Erdoğan sprawował władzę jako premier przez 11 lat, aż do w 2014 roku, kiedy został wybrany na prezydenta Republiki Tureckiej ${ }^{42}$. Duże znaczenie miało wprowadzenie w kraju systemu prezydenckiego na mocy referendum $z$ dnia 16 kwietnia 2017 roku $^{43}$, a także inne zmiany związane ze statusem islamu jako religii w państwie, wzmocnieniem władzy partii AKP, zmiany relacji państwo-armia-społeczeństwo, konfliktu kurdyjskiego oraz konfliktu politycznego z opozycją ${ }^{44}$. Zdecydowana polityka, której azymutem było uczynienie z Turcji silnego państwa i liczącego się gracza na arenie międzynarodowej, budzący wątpliwości sposób rozprawiania się z adwersarzami politycznymi i opozycją, wreszcie skupienie władzy w rękach jednej partii i zwiększenie uprawnień prezydenta były krytykowane przez organy Unii Europejskiej (UE) i największe państwa Europy Zachodniej, co nie pozostało bez wpływu na zachowania konsumenckie turystów z tej części świata.

Jeszcze w 2014 roku Turcję odwiedzały 42 miliony turystów. W 2016 roku było ich zaledwie 24 miliony ${ }^{45}$. Przychody kraju z turystyki przyjazdowej za cały 2016

37 A. Adamczyk, Znaczenie konstytucji tureckiej z 1961 roku dla rozwoju idei państwa prawnego $w$ Turcji, „Zeszyty Prawnicze UKSW” 11, 2011, nr 3, s. 34.

38 Ibidem, s. 35-36.

39 A. Urbaniak, Neoosmanizm. Polityka zagraniczna Turcji okresu rządów partii Sprawiedliwości i Rozwoju (AKP), „Edukacja Humanistyczna” 31, 2014, nr 2, s. 33.

40 Szczegółowo na ten temat: M. Szkudlarek, Od Atatürka do Erdoğana - ewolucja roli religii w Turcji w okresie rządów AKP, „Refleksje” 2014, nr 9, s. 50-69.

41 Więcej na ten temat: K. Bieniek, op. cit., s. 403.

42 A. Urbaniak, op. cit., s. 34.

43 Por. K. Wasilewski, Turcja w okresie przemian: wnioski dla strategii UE, Warszawa 2017, s. 5.

44 Ibidem.

45 G. Power, The UK Foreign Office says the country is 'generally safe' as it starts to rebuild its tourism sector, 24.07.2018, http://www.theweek.co.uk/turkey/93371/how-safe-is-it-to-travel-to-turkey-in-2018 (dostęp: 30.09.2018). 
rok wyniosły 22,1 miliarda dolarów i były niższe o 30\% niż w 2015 roku $^{46}$. Składa się na to wiele rozmaitych przesłanek.

Jeszcze w 2010 roku w Turcji nie miały miejsca wydarzenia Arabskiej Wiosny. Przez kraj - w przeciwieństwie do innych państw dość atrakcyjnych dla turystów poszukujących słońca i plaży - nie przeszła fala protestów i manifestacji, jego władza pozostała niezmieniona. To istotne w kontekście samego rynku usług turystycznych, gdyż Turcja oferowała wypoczywającym podobne produkty jak Egipt, Tunezja czy Maroko. Wydarzenia te nie tylko zdestabilizowały konkurentów rynkowych Turcji i uczyniły ich oferty mniej atrakcyjnymi dla turystów, lecz także dodatkowo warto dodać, że Erdoğan występował w tym czasie w „roli przywódcy państwa demokratycznego, nowoczesnego i zarazem muzułmańskiego, mogącego stanowić model dla podwalin konstytucyjnych w tych krajach"47.

Kryzys uchodźczy rozpoczynający się w 2015 roku z perspektywy Turcji nie okazał się tak drastyczny w skutkach dla jej atrakcyjności turystycznej jak w przypadku Włoch, Niemiec czy Grecji. Wprawdzie Turcja znalazła się wśród głównych szlaków migracyjnych, niemniej w przekazach medialnych brakowało informacji o kontaktach turystów wypoczywających w Turcji z uchodźcami z sąsiadującej Syrii bądź migrantami. Nie zmieniła tego także współpraca między UE a Turcją w zakresie zapobiegania nielegalnym migracjom ${ }^{48}$ - uchodźcy czy migranci przybyli do Turcji znaleźli się w ośrodkach zlokalizowanych z dala od turystów.

Chociaż powyższe wydarzenia były dla Turcji i jej turystyki raczej czynnikami pozytywnie wpływającymi na rynek usług turystycznych, to nie udało się uniknąć problemu terroryzmu. Jak bardzo terroryzm wpływa na zachowania konsumentów i działalność usług turystycznych, możemy się przekonać na przykładzie zestawienia obejmującego lata 2014-2016. W tym okresie w Egipcie zamknięto 37 hoteli, w Tunezji -28 , a w Turcji -42 . Spadła również liczba budowanych obiektów, zmniejszała się liczba turystów, spadały dochody krajów płynące z turystyki. „Taka sytuacja szczególnie dotkliwie wpłynęła zwłaszcza na gospodarkę Egiptu i Turcji, gdzie turystyka należy do podstawowych gałęzi kreujących dochód narodowy"49.

Zagrożenie terrorystyczne $\mathrm{w}$ Turcji było pochodną zarówno polityki wewnętrznej kraju, jak i jego polityki zewnętrznej. Przez półtora roku (od czerwca 2015 roku do 1 stycznia 2017 roku) w Turcji miało miejsce 18 zamachów

46 Turcja: 16 milionów turystów, a rok jeszcze trwa, 7.11.2017, http://turystyka.rp.pl/artykul/1344152. html?referer=redpol (dostęp: 8.11.2018).

47 A. Adamczyk, Quo Vadis Turcjo - koniec europejskiego kierunku w polityce zagranicznej Turcji, „Rocznik Integracji Europejskiej” 11, 2017, s. 37.

48 Zarzadzanie kryzysem związanym $z$ uchodźcami: Komisja składa sprawozdania $z$ realizacji wspólnego planu działania UE-Turcja, Komunikat prasowy Komisji Europejskiej, Bruksela 10.02.2016, europa.eu/rapid/press-release_IP-16-268_pl.pdf (dostęp: 8.11.2018).

49 J. Sokołowski, Wplyw ataków terrorystycznych na popyt i podaż $w$ usługach turystycznych, „Prace Naukowe Uniwersytetu Ekonomicznego we Wrocławiu” 2017, nr 487, s. 288. 
terrorystycznych ${ }^{50}$, w których zginęło ponad 400 osób. Było to pokłosie zaangażowania Turcji w walkę z Państwem Islamskim w Syrii i Iraku, a także wewnętrznego konfliktu z mniejszością kurdyjską. Zaowocowało to wydawaniem przez ministerstwa spraw zagranicznych poszczególnych krajów ostrzeżeń dla osób wybierających destynacje w Turcji. Prezydent kraju zapowiedział ukaranie zamachowców ${ }^{51}$ oraz zrealizowanie planów „skutecznego uniemożliwienia planowania ataków w niedalekiej przeszłości” ${ }^{52}$, niemniej rzeczywista liczba turystów spadła. Pomijając zamachy w największych miastach (Stambuł, Ankara), ich lokalizacje nie stanowiły miejsc przebywania turystów. Kurorty i główne atrakcje turystyczne kraju (Efes, Pamulale, Kapadocja) nie zostały dotknięte terrorem. Poza tym akty terroru realizowane przez bojowników kurdyjskich były skierowane przeciw aparatowi państwa i jego funkcjonariuszom. Z wyłączeniem Stambułu i w przeciwieństwie do Tunezji i zamachu w Susie w 2015 roku, Egiptu i ataku nożownika na plaży w 2017 roku czy zamachu terrorystycznego we francuskiej Nicei z 2016 - turyści jako osoby odwiedzające dany kraj nie byli głównym celem ataku. Informacje medialne o zamachach oraz alerty poszczególnych państw wpłynęły jednak na zachowania konsumentów usług turystycznych. Innym czynnikiem, który negatywnie zdawał się wpływać na atrakcyjność turystyczną i wypoczynkową Turcji, była nieudana próba przeprowadzenia puczu wojskowego, skierowanego przeciw prezydentowi Erdoğanowi. Co istotne, wydarzył się w samym sercu sezonu wakacyjnego (15-16.07.2016). Represje dotknęły osób podnoszących rękę na władzę ${ }^{53}$. W czasie trwania stanu nadzwyczajnego na mocy nadzwyczajnych dekretów prawie 110 tysięcy pracowników sektora publicznego zostało wyrzuconych z pracy, a dziesiątki tysięcy innych zawieszono, tysiące ludzi uwięziono ${ }^{54}$. Sama sytuacja kryzysu nie pozostała również bez wpływu na zachowania turystów. Spowodowała dyskusję w kręgach europejskich co do zasadności i proporcjonalności zastosowanych przez władze państwowych sankcji. Ów dyskurs o Turcji jako kraju totalitarnym/autorytarnym mógł okazać się istotny dla części potencjalnych konsumentów. Jak pokazały badania niemieckiego stowarzyszenia na rzecz rozwoju turystyki (Studienkreis für Tourismus und Entwicklung), kryzys spowodowany puczem oraz napiętymi stosunkami Niemcy-Turcja wpłynął ilościowo i jakościowo na zainteresowanie niemieckich turystów Turcją. Nie tylko

50 Zobacz na mapie: Turcja celem zamachowców, 1.01.2017, https://www.polityka.pl/tygodnikpolityka/swiat/1688974,1,zobacz-na-mapie-turcja-celem-zamachowcow.read (dostęp: 30.09.2018).

51 Ibidem.

52 K. Godfrey, Turkey holiday travel advice: Latest update as terror attacks 'very likely', 5.06.2018, https://www.express.co.uk/travel/articles/969707/turkey-holiday-flights-travel-advice-terror-attacks-latest-news-istanbul-ankara/amp (dostęp: 30.09.2018).

${ }^{53}$ A. Gersz, Turcja: Trwaja represje po nieudanym puczu. Aresztowano tysiace wojskowych, sędziów i urzędników, 18.07.2016, https://polskatimes.pl/turcja-trwaja-represje-po-nieudanym-puczu-aresztowano-tysiace-wojskowych-sedziow-i-urzednikow/ar/10419184 (dostęp: 1.10.2018).

54 Turcja - koniec stanu wyjątkowego, Polskie Radio, 19.07.2018, https://www.rp.pl/Rozmaitosci/307199963-Turcja---koniec-stanu-wyjatkowego.html (dostęp: 1.10.2018). 
spadła liczba turystów z Niemiec, ale wyjazdu do Turcji unikały też osoby, które wcześniej tam nie były, seniorzy, osoby z wyższym wykształceniem i najbogatsze, ze sfer wyższych oraz te szczególnie przywiązane do zachowania wysokich standardów politycznych, moralnych i ochrony środowiska ${ }^{55}$.

Rok 2018 przyniósł ugruntowanie władzy rządzącej opcji politycznej, legitymizowane wyborami. W przededniu sezonu turystycznego pojawily się wprawdzie informacje o potencjalnym zagrożeniu terrorystycznym oraz niestabilności kraju ${ }^{56}$, ale w pierwszym przypadku ludzka pamięć działała selektywnie wobec atrakcyjnej oferty wyjazdu, w drugim zaś część podróżnych zakładała, że wpływ potencjalnych protestów i manifestacji na ich pobyt będzie relatywnie mały. Warto dodać, że 18 lipca 2018 roku zakończył się w Turcji stan wyjątkowy ${ }^{57}$, co moglibyśmy interpretować jako powrót stabilizacji. Polskie Ministerstwo Spraw Zagranicznych nadal ostrzegało przed podróżą do kraju, wskazując na potencjalne zagrożenie terroryzmem w największych miastach (Stambuł oraz Ankara) oraz zalecając unikanie części wschodniej kraju - na podstawie zachowań konsumenckich polskich turystów trudno jednak mówić o istotnym wpływie tych ostrzeżeń na wybory Polaków.

Turystyka turecka zaczęła się odradzać głównie dzięki turystom z Rosji w drugim kwartale 2017 roku $^{58}$, co było zapowiedzią sukcesów w roku kolejnym. Mimo że obecnie nie jest możliwe podanie precyzyjnej liczby turystów za 2018 rok, przyjmuje się, że będzie on dla tureckiej branży turystycznej korzystny. Jeszcze w czasie trwania sezonu oceniano, że kraj odwiedzi około 40 milionów turystów, przychody branży turystycznej zamkną się zaś w sumie 32 miliardów euro ${ }^{59}$. W 2016 roku kraj odwiedziło 25,3 miliona gości, dwa lata wcześniej — aż 36,8 miliona. W 2015 roku dochody z turystyki wyniosły 31,4 miliarda dolarów, w 2016 roku — zaledwie 22,1 miliarda. Rok później (2017) wzrosły już one do 26,3 miliarda dolarów ${ }^{60}$.

Dobry sezon turystyczny zapowiadał już pierwszy kwartał 2018 roku. Od stycznia do marca przyjechało do Turcji 7,26 miliona turystów, czyli o 50,6\% więcej niż w $2017 \mathrm{roku}^{61}$. Wśród nich dominowali obcokrajowcy (5,21 miliona), ale dużą część stanowili też Turcy mieszkający poza krajem rodzinnym (2,1 miliona).

${ }^{55}$ M. German, Niemcy podróżują etycznie, 19.06.2018, https://www.rp.pl/Obyczaje/180619268Niemcy-podrozuja-etycznie.html (dostęp: 1.10.2018).

56 K. Godfrey, op. cit.

57 Turcja - ostrzeżenie dla podróżujących, Komunikat Ministerstwa Spraw Zagranicznych, 29.08.2018, https://msz.gov.pl/pl/informacje_konsularne/ostrzezenia/turcja__ostrzezenie_dla_ podrozujacych_1 (dostęp: 1.10.2018).

58 Turcja: 16 milionów turystów...

59 M. German, Turecka branża turystyczna zadowolona z ruchu turystów, 22.08.2018, https:// www.rp.pl/Obyczaje/308229997-Turecka-branza-turystyczna-zadowolona-z-ruchu-turystow.html (dostęp: 22.08.2018).

60 M. German, Tureckie hotele prawie wyprzedane, 16.07.2018, https://www.rp.pl/Biura-podrozy/307169977-Tureckie-hotele-prawie-wyprzedane.html (dostęp: 2.08.2018).

61 M. German, 100 procent Polaków w Turcji więcej, 25.05.2018, https://www.rp.pl/Obyczaje/305259996-100-procent-Polakow-w-Turcji-wiecej.html (dostęp: 2.08.2018). 
Portale branżowe informowały, że w 2018 roku liczba turystów z Niemiec i Wielkiej Brytanii w Turcji w stosunku do ubiegłego roku wzrośnie nawet o $80 \%{ }^{62}$. Finalnie pod koniec sezonu wakacyjnego odwiedziło kraj około 5 milionów Niemców (w 2015 roku padł rekord i turystów z Niemiec było 5,4 miliona) ${ }^{63}$. Było to o tyle istotne, że w 2016 roku liczba turystów z Niemiec spadła w porównaniu z rokiem poprzednim o 31\%, a w 2017 roku nastąpił spadek o kolejne $4 \%{ }^{64}$.

W lipcu wskazywano, że obłożenie tureckich hoteli sięgnie w szczycie sezonu (lipiec i sierpień) $100 \%{ }^{65}$, nawet w obiektach położonych nad Morzem Czarnym ${ }^{66}$. W drugiej połowie sierpnia 2018 roku w popularnym kurorcie Alanya nie było już wolnych miejsc w hotelach ${ }^{67}$, co było spowodowane przyjazdem gości z zagranicy.

Wzrost dotyczył przede wszystkim turystyki masowej, co interpretuje się jako konsekwencję wysiłków podjętych przez sektor turystyczny, a także realnego wsparcia rządu w zakresie zachowania bezpieczeństwa i stabilności kraju oraz dofinansowania lotów czarterowych, co pozwalało obniżyć ceny końcowe dla klientów ${ }^{68}$. Polscy turyści w sytuacji zagrożenia terroryzmem w Turcji zachowali się podobnie do turystów z innych państw. W 2016 roku odnotowano spadek rezerwacji o 58,5\% w stosunku do poprzedniego roku, przez co kraj znalazł się na czwartej pozycji wśród kierunków wybieranych w systemie rezerwacyjnym biur podróży ${ }^{69}$. W 2017 roku turecka branża turystyczna szacowała, że przyjęto około 300 tysięcy turystów z Polski. Pod koniec 2017 roku zakładano, że w kolejnym roku (2018) ta liczba będzie wyższa i wyniesie około 500 tysięcy $^{70}$. W tym przypadku także nie znamy jeszcze danych całościowych, ale pewną informację stanowią dla nas dane z pierwszego kwartału 2018 roku. Od stycznia do marca 2018 roku przyjechało do Turcji 26,3 tysiąca Polaków, czyli o 97,5\% więcej niż w analogicznym okresie poprzedniego roku. Daje to udział w rynku na poziomie $0,51 \%{ }^{71}$, co, biorąc pod uwagę inne nacje, nie wydaje się wysoką wartością. Niemniej od początku

${ }^{62}$ M. German, Hiszpania traci na niskich cenach Turcji, 5.07.2018, https://www.rp.pl/ Hotele/307059968-Hiszpania-traci-na-niskich-cenach-Turcji.html (dostęp: 2.08.2018).

63 M. German, W Niemczech sprzedaż Turcji rośnie dwucyfrowo, 13.09.2018, https://www. rp.pl/Biura-podrozy/309139984-W-Niemczech-sprzedaz-Turcji-rosnie-dwucyfrowo.html(dostęp: 2.10.2018).

64 M. German, Niemcy podróżują...

65 M. German, Tureckie hotele...

${ }^{66}$ Ze względu na odległości od lotnisk jest to region stosunkowo słabo spenetrowany przez turystów zagranicznych.

67 M. German, Hotele w Alanyi obłożone w 100 procentach, 17.08.2018, https://www.rp.pl/ Obyczaje/308179978-Hotele-w-Alanyi-oblozone-w-100-procentach.html (dostęp: 1.10.2018).

68 M. German, Turecka branża...

69 Polski Związek Organizatorów Turystyki, Polish Tourism 2015/16 from the perspective of Polish Tour Operators Association \& MerlinX, http://www.pzot.pl/tempOpen/default/files/00000002 ET0Q00MK25BQAWS7516GLA26_Turism2015_16_PZOT_MerlinX.pdf.

70 Turecka turystyka liczy na pót miliona Polaków, 18.12.2017, http://turystyka.rp.pl/artykul/1349321.html?referer=redpol (dostęp: 10.09.2018).

71 M. German, 100 procent Polaków... 
roku do finału okresu wakacyjnego - jak pokazują tygodniowe raporty Polskiego Związku Organizatorów Turystyki - Turcja sytuowała się na drugiej pozycji wśród wybieranych destynacji ${ }^{72}$. Na przykład - w 20. tygodniu (druga połowa maja 2018 roku) liczba rezerwacji w Turcji wzrosła w stosunku do analogicznego tygodnia poprzedniego roku o $213,3 \%$, przyloty polskich turystów na lotnisko w Antalyi o $187,2 \%$, a na lotnisko w Bodrum o $249,4 \%{ }^{73}$. W czasie sezonu wakacyjnego te wzrosty nie były już tak duże, pokazywały jednak wyraźne zainteresowanie polskich turystów Turcją. Raport Polskiej Izby Turystyki ${ }^{74}$ dotyczący rezerwacji wykonywanych za pośrednictwem biur podróży dokonanych w dniach 28 kwietnia 2018-31 sierpnia 2018 pokazał nie tylko wzrost zainteresowania turystyką zagraniczną Polaków w stosunku do poprzedniego roku (wycieczki czarterowe wykupiło 1,4 miliona Polaków, o 36\% więcej niż w 2017 roku), ale także pokazuje, że Turcja (14,9\%) znalazła się na drugim miejscu za Grecją (31,6\%). Najczęściej odwiedzanym przez turystów miejscem okazała się Riwiera Turecka $(11,1 \%$ wszystkich rezerwacji). Turcja była także na drugiej pozycji pod względem dynamiki tanich wyjazdów (wzrost w stosunku do poprzedniego roku o 168\%), acz tu zdecydowanym liderem była Tunezja powracająca do grona popularnych kierunków turystycznych po latach nieobecności spowodowanych kryzysem politycznym i zamachem w Susie (wzrost o 494\%).

\section{Metodologia badania}

W części analitycznej niniejszego artykułu poddano analizie jakościowej opinie osób uczestniczących w wyjazdach wakacyjnych zorganizowanych przez poszczególne biura podróży, opublikowane na portalu Wakacje.pl. Już wiele lat temu Wanda Patrzałek wskazywała że nowym trendem konsumpcji stało się przenoszenie zakupów do sieci ${ }^{75}$. Wybór oferty wyjazdu zagranicznego w sieci pozwala turyście przeanalizować poszczególne atrybuty, dokonać weryfikacji ocen, sprawdzić opinie innych klientów. Wakacje.pl to portal, na którym dostępne są oferty wielu biur podróży, co zapewnia pewną różnorodność touroperatorów, dodatkowo wieloletnia obecność na rynku sprawia, że raczej nie pojawiają się w tym przypadku obawy co do zakupów $\mathrm{w} \operatorname{sieci}^{76}$. Z perspektywy niniejszej analizy

$72 \mathrm{http}: / /$ www.pzot.pl/index.php?module=cms/files\&group=Raporty\%20PZOT (dostęp: 10.10.2018).

73 Polski Związek Organizatorów Turystyki, Weekly Report 20/2018, 22.05.2018, http:// www.pzot.pl/tempOpen/default/files/000000025R737YPYGZW2XG40RYAOE51C_Booking_ Report_20_2018.pdf (dostęp: 10.10.2018).

74 Zagraniczne wakacje Polaków 2018, https://www.travelplanet.pl/blog/zagraniczne-wakacje-polakow-2018-raport-polskiej-izby-turystyki/ (dostęp: 10.10.2018).

75 W. Patrzałek, Czynniki kulturowe wplywające na zachowania konsumentów, [w:] Kulturowe determinanty zachowań konsumenckich, red. W. Patrzałek, Wrocław 2004, s. 34.

${ }^{76} \mathrm{Na}$ co m.in. wskazywali młodzi konsumenci, wypowiadając się o zakupach w sieci. Por. J. Wardzała, Zmiany w postrzeganiu roli młodzieży we współczesnym społeczeństwie konsumpcyjnym, 
istotne jest to, że możliwość napisania własnej oceny mają tylko osoby faktycznie wykupujące daną usługę. Dodatkowo przyjęto, że opinie publikowane na portalu nie są poddawane cenzurze: potwierdzały to zarówno doświadczenia własne, jak $i$ to, że we wpisach pojawiały się negatywne oceny samego portalu i jego profesjonalizmu, a także poszczególnych touroperatorów - partnerów serwisu. Portal ${ }^{77}$ pośredniczy w sprzedaży usług turystycznych oferentów, wśród których są nie tylko największe biura podróży działające w Polsce (Itaka, Exim Tours, Grecos, Neckermann, Rainbow, TUI), lecz także touroperatorzy mniejsi, dla których ta płaszczyzna komunikacji z klientem jest kluczowa.

Głównym problemem badawczym było to, jakie elementy usług hoteli o najwyższym standardzie w Turcji turyści uważają za atrakcyjne w czasie wypoczynku zagranicznego, a które kwestie są przez nich oceniane negatywnie. Zakładano, że turyści, wybierając określone usługi i zapoznając się ze szczegółami ofert, będą poddawać ocenie te elementy, które były im wcześniej znane, niemniej to, czy ocena ta będzie pozytywna, czy negatywna, będzie uzależnione od tego, w jakim stopniu usługa odbiegała od ich początkowych oczekiwań.

Zdecydowana większość dokonywanych w 2018 roku rezerwacji w Turcji obejmowała hotele cztero- i pięciogwiazdkowe ${ }^{78}$. Analizie poddano 500 postów internautów, zamieszczonych jako opinie klientów hoteli pięciogwiazdkowych, czyli tych, które oferowały najwyższy poziom usług. Zastosowana metoda (analiza jakościowa) oraz ramy niniejszego artykułu narzuciły taką formę, choć z pewnością interesujące byłoby sięgnięcia po materiał wtórny odnoszący się do destynacji pobytowych o niższym standardzie. $\mathrm{W}$ toku analizy wyodrębniono zagadnienia, które okazały się kluczowe dla turystów z Polski. Były to:

- hotel,

— odległość/lokalizacja i otoczenie hotelu,

- wyżywienie i realizacja opcji all inclusive,

- pokoje będące w dyspozycji gości,

- personel i jego praca,

- usługi w obiekcie hotelowym,

- baseny,

- plaża.

[w:] Konsumpcja jako forma komunikacji społecznej. Nowe paradygmaty i konteksty badawcze, „Prace Naukowe Uniwersytetu Ekonomicznego we Wrocławiu" 2015, nr 414, red. W. Patrzałek, s. 257.

77 Jak czytamy w opisie, Wakacje.pl to „pionier polskiej e-turystyki i największy multiagent turystyki wyjazdowej [...]”. Firma prowadzi działalność na trzech płaszczyznach. Kanałami dystrybucji są: internet, call center, ponad 90 salonów sprzedaży. Por. Polska Izba Turystyki, Zagraniczne wakacje Polaków 2017, Warszawa 2017.

78 Polska Izba Turystyki, Zagraniczne wakacje Polaków 2018, Konferencja prasowa Polskiej Izby Turystyki, Warszawa 6.09.2018, http://www.pit.org.pl/media/1/002/009/2129.pdf (dostęp: 20.09.2018). 
Wymienione kategorie są tylko częściowo zbieżne tematycznie z opisami ofert, które analizowali konsumenci, podejmując decyzję o wyborze konkretnej usługi. Nabywcy oceniali w sieci ofertę którą zakupili, i porównywali ją z realiami. Chwalili lub krytykowali obiekt, wskazywali niuanse skrótowych opisów i realia dostępności wykupionej usługi. Dlatego też lektura wypowiedzi internautów pozwala pośrednio poznać preferencje i oczekiwania turystów, którzy chętnie porównują zakupioną ofertę z rzeczywistością pobytu.

\section{Atrakcyjne strony wybranej oferty}

Konsumenci zorganizowanej usługi turystycznej wybierający hotele o najwyższej liczbie gwiazdek przynajmniej teoretycznie powinni otrzymać ofertę o bardzo wysokim standardzie. Obiekt powinien mieć atrakcyjne usytuowanie, profesjonalną obsługę, wiele dodatkowych usług oferowanych przez hotel, duże i atrakcyjne pokoje, różnorodne wyżywienie itp. Każda z tych kwestii może być jednak inaczej rozumiana, nie mówiąc już o atrybutach, które nie są ujęte w kategoryzacji. Stąd też próba odpowiedzi na pytanie o to, jakimi atrybutami cenionymi przez turystów cechowały się ocenione oferty.

\subsection{Hotel}

Hotele pięciogwiazdkowe to duże obiekty, które mogą przyjąć nawet kilkuset gości. Z perspektywy osób wypowiadających się na forum istotne było to, aby przebywanie na terenie dość dużego skupiska ludzi nie było odczuwalne w czasie wypoczynku, korzystania $\mathrm{z}$ atrakcji hotelu oraz posiłków. Cenione są zatem hotele, które zajmują rozległy teren, zagospodarowany w zróżnicowany sposób, a ich położenie geograficzne pozwala cieszyć się urokami wizualnymi kraju (widok na góry). Poza rozbudowaną infrastrukturą (baseny, bary) istotne jest także obcowanie z przyrodą: ogród, drzewa czy nawet spacerujące po obiekcie ptaki. Rozległy teren, kwiaty, krzewy i drzewa zapewniają spokój i intymność, dają możliwość wypoczynku. Przy takiej infrastrukturze oddalenie od innych atrakcji hotelowych nie jest postrzegane jako element negatywny. Opiniodawcy zwracają uwagę na zaangażowanie obsługi hotelowej - roślinność jest bujna i kolorowa, ponieważ codziennie nad ranem jest podlewana, oswojone zwierzęta są zdrowe, czyste i przyjazne. Na trawnikach i ścieżkach nie ma zeschniętych liści i kwiatów, a tym bardziej śladów bytności kotów czy ptaków, gdyż na bieżąco są one usuwane - obiekt jest non stop sprzątany, jest czysto. Generalnie obiekty rozległe terytorialnie są cenione, pod warunkiem że ich infrastruktura jest zdecentralizowana - istnieją różne bary i restauracje, w których nie ma tłoku, są baseny adresowane do osób pragnących ciszy i tych, którym nie przeszkadza głośna muzyka, a także place zabaw i baseny dla najmłodszych. Zdarza się, że rozległość obiektu generu- 
je utrudnienia dla przyjezdnych, zmusza ich do przemieszczania się. Oczywiście niektórzy turyści wskazują, że ze względu na ich chęć poruszania się spacer na obiad czy do drink baru w pięknym otoczeniu nie stanowi dysfunkcji hotelu, niemniej w innych wypowiedziach traktuje się to właśnie jako pewną niedogodność.

Jeśli obiekt hotelowy jest jedną bryłą, pojawiają się rozmaite problemy, które zostaną wskazane w dalszej części artykułu. Ale są także zalety. Wysokość obiektu wiąże się z atrakcyjnym widokiem z pokoju oraz części ogólnodostępnych (możliwość stworzenia restauracji na dachu), względną homogenizację pokoi (brak pokoi oddalonych od budynku centralnego czy głównych atrakcji), bardziej spektakularny estetycznie wystrój części wspólnych (złocenia, kryształowe żyrandole itp.). Dodatkowo tego typu obiekt jest widoczny z daleka, może wyróżniać się z miejscowej zabudowy, budząc dumę turystów wypoczywających w owym „pałacu”.

\subsection{Lokalizacja i otoczenie hotelu}

Wśród turystów cenione są przede wszystkim obiekty, które usytuowane są w relatywnie małej odległości od lotniska, takie, do których transfer docelowy zajmuje około godziny. Wprawdzie turyści dysponują informacjami na ten temat w momencie wyboru oferty, niemniej część internautów podkreśla, że odległość od lotniska była zaletą pobytu w obiekcie. Kwestia najbliższego otoczenia hotelu w wypowiedziach pojawia się raczej marginalnie: turyści cenią bliskość miejscowości lub miasta, lecz sytuacji pewnego oddalania nie interpretują jako dysfunkcji wybranej oferty. Jeśli większa miejscowość czy miasto jest względnie niedaleko, można udać się tam na zakupy w każdej chwili, pozwiedzać lokalne atrakcje. Ale jeśli tak nie jest, nie stanowi to czynnika wyraźnie obniżającego postrzeganie wypoczynku. Niektóre z hoteli oddalonych od tego typu atrakcji oferują bezpłatne dojazdy do najbliższych miejscowości, gdzie są sklepy, targi, atrakcje turystyczne, a inne nie widzą takiej potrzeby. Być może ta kwestia byłaby częściej artykułowana, gdyby nie było realnie dostępności z każdego obiektu do tak zwanych dolmuszy, czyli busów komunikacji publicznej jeżdżących za symboliczną opłatą do atrakcyjnych dla turystów miejsc i miejscowości. Co ciekawe, to właśnie dolmusze są wskazywane jako atrakcyjny środek przemieszczania się po okolicy, tylko śladowo pojawia się kwestia korzystania z usług prywatnych przewozów taxi. Jeśli chodzi o najbliższą okolicę, to niekiedy pojawia się temat najbliższego otoczenia hotelu w kontekście spacerów czy - stosunkowo rzadko - uprawiania sportu. Cenione jest tu szczególnie bezpieczeństwo turystów w przestrzeni publicznej oraz względnie atrakcyjna infrastruktura lokalna dostępna bezpośrednio w pobliżu niektórych hoteli (długie i zadbane promenady, ławki, trakty rowerowe). 


\subsection{Wyżywienie i realizacja opcji all inclusive}

Bogata oferta posiłków, zróżnicowanie, organizowanie tak zwanych wieczorów tematycznych, możliwość przyjścia na posiłek w ostatniej chwili - właśnie te elementy usługi turystycznej pojawiają się najczęściej, kiedy internauci dokonują oceny posiłków. Potrawy nie powtarzają się, mają odpowiednią temperaturę, nie ma problemu z ich dostępnością. Oczywiście nie ma także problemów z dostępnością stolików, gdzie można owe posiłki skonsumować - tak moglibyśmy podsumować pozytywne wpisy internautów. Atrakcją są potrawy lokalne przygotowywane przez kucharza w sali restauracyjnej i bezpośrednio wydawane gościom, ceni się zróżnicowanie mięs i zup oraz owoców. Internauci podkreślają nie tylko swobodny dostęp do stolików, ich czystość (szybkie uprzątnięcie po wcześniejszych gościach i zmienianie obrusów), ale także to, że kelnerzy podchodzą do nich, pytając o preferowane napoje. Pojawiają się pozytywne oceny restauracji à la carte, jednak pod warunkiem, że dotyczą konkretnej kuchni i że ich oferta przewyższa jakością to, co pojawia się w czasie głównych posiłków.

Zdecydowana większość ofert pobytów wczasowych w Turcji jest realizowana $\mathrm{w}$ formie all inclusive, co oznacza, że na terenie obiektu zaspokaja się wszystkie potrzeby gastronomiczne gości. Oczywiście w opisach niektórych obiektów pojawiają się pewne ograniczenia i obostrzenia (liczba miejsc realizacji usług, godziny, typy usług itp.). Internauci będący gośćmi hoteli pięciogwiazdkowych już na poziomie wyboru oferty zapoznają się z jej ograniczeniami, które jednak w przypadku obiektów o tym standardzie są dość nieznaczne. Stąd też chwalenie obiektów za długi czy rzadziej - całodobowy dostęp do wyżywienia i napojów, ujęcie w bezpłatnym pakiecie rozmaitych form pożywienia poza trzema posiłkami (przekąski, tak zwana nocna zupa, ciepłe przekąski, potrawy lokalne i pizza pieczona na oczach turystów), lodów (szczególnie kiedy są bezpłatne nie tylko dla dzieci, ale także dla dorosłych). Atrakcyjne jest uzupełnianie barku w pokoju różnymi bezpłatnymi butelkowanymi napojami (cola, soki), lodówki w obiekcie, z których można w każdej chwili pobrać butelkowaną wodę. Turcja jest krajem islamskim, powrót do religijnych źródeł jest widoczny w polityce władz państwowych, co z kolei wiąże się z wysokością cen i dostępnością alkoholi w kraju. Stąd też hotele, w których oferowane są bezpłatnie nie tylko alkohole krajowe, ale przede wszystkim - importowane, cieszą się uznaniem turystów. Napoje alkoholowe powinny być nie tylko zróżnicowane - ważne jest także, ile zawierają alkoholu. Zadowoleni turyści piszą o „uczciwych” i „nierozcieńczanych” drinkach, wyglądających przy tym estetycznie, najlepiej z dodatkami naturalnych soków i oryginalnych napojów niealkoholowych, przygotowywanych sprawnie przez barmanów, serwowanych od ręki, bez konieczności czekania. 


\subsection{Pokoje}

Jeśli chodzi o same pokoje, to ceniona jest $\mathrm{w}$ nich estetyka i funkcjonalność, jakość produktów, które są codziennie dostarczane gościom (szampon, żel pod prysznic, balsam itp.), czy też nowoczesność wyposażenia (telewizor LCD). Ważne, aby pokój był czysty i dokładnie sprzątany, nawet kiedy nie zostawi się napiwku. Kluczową sprawą jest też to, by był odnowiony, nie było śladu pobytów innych osób, a w toku pobytu był perfekcyjnie sprzątany. Dla większości turystów atrakcyjny jest widok na morze (oferowany jednak tylko przez część hoteli). Przez niektórych gości cenione są pokoje zapewniające ciszę i poczucie intymności. Niektórzy są zadowoleni z tego, że widok z pokoju obejmuje atrakcje infrastruktury hotelowej (basen, amfiteatr), inni jednak preferują pokoje, w których zamieszkiwanie nie wiąże się z nadmiernym hałasem (głośna muzyka puszczana przy basenie, występy, animacje lub dyskoteka kończące się w późnych godzinach nocnych). Ważne, aby grubość ścian między pokojami pozwalała nie słyszeć innych gości. Niektórzy goście, opisując swój pobyt w hotelu, podkreślają, że wszystkie pokoje mają jednakowy standard, że nie ma pokoi gorszych i lepszych, jeśli chodzi o wygląd wewnętrzny i termin odnowienia.

\subsection{Personel i jego praca}

W obiektach hotelowych, które wyłoniono do analizy wpisów internautów, Polacy stanowią mniejszość. Z tego powodu nikt z internautów nie oczekuje od personelu mówienia $\mathrm{w}$ języku polskim, ale język angielski jest traktowany jako obowiązkowy. Stąd też pochwały dla niektórych obiektów, że językiem tym operuje nie tylko kierownictwo i recepcja, ale także pracownicy liniowi: kelnerzy czy barmani, czy nawet osoby sprzątające pokoje (w wypowiedziach internautów to zawsze kobiety). Personel musi być kompetentny i rozwiązywać problemy gości, czynić to z uśmiechem, w ekspresowym tempie. Personel recepcji poza wysokim sezonem zmienia pokój na inny na prośbę gościa, osoba sprzątająca odwiedza pokój w tych godzinach, kiedy wczasowicze korzystają z basenu lub plaży, osoby odpowiedzialne za serwowanie posiłków donoszą dynamicznie kolejne patery, a osoby zajmujące się utrzymaniem czystości w restauracji/barze szybko sprzątają po gościach, zmieniają obrusy i rozkładają sztućce dla następnych. Gość hotelu pięciogwiazdkowego ceni sobie to, że w wielu miejscach może otrzymać napój, ale za istotne uważa także to, że siadając do posiłku jest pytany przez obsługę, co mu przynieść do picia. Pracownicy odpowiedzialni za czystość obiektu są cały czas zaangażowani w swoje zadania i usuwają powstające usterki, acz gros ich zajęć realizowane jest wtedy, kiedy turyści nie są obecni w przestrzeni publicznej (gruntowne sprzątanie basenu w czasie kolacji, podlewanie kwiatów — nad ranem). 


\subsection{Usługi w obiekcie}

Zakres usług w obiektach o najwyższej standardach powinien być różnorodny i rzeczywiście na stronach poszczególnych hoteli natrafiamy na informacje o własnej dyskotece, centrum SPA z rozmaitymi usługami, centrum konferencyjnym, siłowni i krytym basenie, usługach prania i prasowania, nie mówiąc już o animacjach i opiece nad dziećmi. W wypowiedziach internautów te walory są jednak wskazywane stosunkowo rzadko. Internauci nie odwiedzają hotelu w celach biznesowych, w sezonie mają wiele innych atrakcji niż siłownia (w kurortach istnieją przy promenadach nadmorskich siłownie publiczne na otwartym powietrzu) czy basen zamknięty. Okazjonalnie pojawiają się opinie na temat usług odnowy biologicznej i ich jakości, stosunkowo często poddawane są ocenie dostępne animacje. „Idealni” animatorzy - czyli zespół najczęściej młodych ludzi, którzy mają umilić pobyt wczasowiczom - są przede wszystkim nienarzucający się, otwarci i zaangażowani w swoją pracę. Potrafią adresować swe usługi do rozmaitych kategorii turystów: dzieci, osób młodych, osób starszych. Znają języki obce, gry i zabawy prowadzą w językach, które znają wszyscy goście (angielski), a nie tylko ich większość (rosyjski, niemiecki). Cechą pozytywną jest zaangażowanie w pracę i indywidualne podejście do gościa. Nie wszyscy goście są nastawieni na korzystanie z usług animatorów, stąd też znaczenie owego „nie narzucania się". W niektórych hotelach są animatorzy narodowości polskiej, opłacani przez większe biura podróży. Dla gości, którzy zwracają uwagę na ten segment usług pobytowych, jest to istotne, szczególnie jeśli oferta adresowana jest do dzieci.

\subsection{Baseny}

Hotele o najwyższym standardzie dysponują basenem, bardzo często basenami. Wiele $\mathrm{z}$ nich jest wyposażonych $\mathrm{w}$ rozmaite atrakcje wodne, takie jak zjeżdżalnie, bary $\mathrm{w}$ wodze czy baseny typu infinity. Optymalnym rozwiązaniem jest decentralizacja basenów i adresowanie ich do konkretnych targetów (grup docelowych): osób, które chcą przy basenie słuchać głośnej muzyki i brać udział $\mathrm{w}$ animacjach, które chcą skorzystać z elementów aquaparku, tak zwanych cichych basenów oraz płytkich basenów, najczęściej ze zjeżdżalniami i podobnymi udogodnieniami przygotowanymi z myślą o rodzinach z dziećmi. Baseny powinny być nadzorowane przez obsługę - powinna być ona wyczulona na zachowania gości niezgodne z regulaminem, ale także musi zwracać uwagę na czystość wody oraz otoczenia basenu. Ważne są także uważność ratowników i bezpieczeństwo. Rozrzucenie obiektów wodnych na terenie hotelu jest chwalone przez turystów, gdyż dzięki temu mają wybór, ale przede wszystkim ceni się tu dostępność o każdej porze leżaków i parasoli. 


\subsection{Plaża}

Najwyżej stawiana jest plaża wchodząca w skład obiektu hotelowego, która jest szeroka i piaszczysta. Plaża i morze powinny być czyste. Doceniane są elementy jej infrastruktury (leżaki, bar czy restauracja, własny pomost) oraz ich jakość. Ważny jest poziom ochrony samych gości (liczba punktów i osób zaangażowanych w ochronę, ich reakcje na wejście na teren plaży hotelowej osób niebędących gośćmi) i ich bezpieczeństwa (ratownik/ratownicy, punkt medyczny, motorówka itp.). O ile część tych usług może być zapewniona przez kierownictwo hotelu i jego załogę, o tyle kwestia samego dostępu do morza i plaży stanowiła „dobrodziejstwo inwentarza”, kiedy decydowano o budowie obiektu. Część hoteli pięciogwiazdkowych zajmujących dość duży teren jest oddalona od morza o kilkaset metrów bądź kilometr, co rekompensowane jest gościom przez zapewnianie kursujących bezpłatnie busów. $\mathrm{Z}$ wypowiedzi internautów wynika, że to rozwiązanie działa dobrze, gdyż busy kursują non stop, a sam obiekt rozszerza swoją bazę restauracyjno-barową tak, że część gości spędza nad morzem całe dnie bez konieczności wracania na posiłki do hotelu. Plaża ma być czysta, co oznacza, że nawet jeśli część gości nie będzie poczuwała się do sprzątania po sobie, obsługa zadba o to, aby w piasku nie było niedopałków po papierosach albo plastikowych kubków po napojach. W niektórych wypowiedziach pojawia się kwestia wielkości plaży i braku problemów z zajmowaniem miejsc. Internauci cenią sobie także przestrzeń między poszczególnymi kompletami leżaków i parasoli, wreszcie nowość i wygodę leżaków.

\section{Niedociągnięcia hoteli i rozczarowania konsumentów}

Teoretycznie goście najwyżej klasyfikowanych obiektów powinni byli otrzymać usługę w pełni ich satysfakcjonującą. Teoretycznie - gdyż wśród wpisów pojawiały się także opinie negatywne ${ }^{79}$. Podobnie jak w przypadku cech wyróżnionych na korzyść obiektów, dotyczyły one samego obiektu i jego otoczenia, personelu, infrastruktury — jej dostępności i jakości.

\subsection{Sam hotel}

Obiekty pięciogwiazdkowe są zazwyczaj duże w tym znaczeniu, że usługi świadczą w tym samym czasie wielu gościom. Tylko niektóre znajdują się na rozległym terenie, stąd też tylko część hoteli ma charakter zdecentralizowany. Formy zdecentralizowane to najczęściej zespoły osobnych budynków połączonych

79 Por. J. Wardzała-Kordyś, Opinie o produktach wadliwych i aktywność reklamacyjna gospodarstw domowych, [w:] A. Dejnaka et al., Działalność informacyjna członków gospodarstwa domowego i jego decyzje ekonomiczne, Warszawa 2012, s. 176. 
traktami pieszymi, otoczonych roślinnością, między którymi zlokalizowane są dodatkowe atrakcje: rozmaite baseny, altany, place zabaw. Niekiedy jednak hotele to jednorodne budynki o różnych kształtach, w których kilkaset osób mieszka w tym samym miejscu. Ma to swoje konsekwencje, jeśli chodzi o ruch turystów i przemieszczanie się, ale także, co zdaje się zarzutem prymarnym — dostępność infrastruktury. Zazwyczaj towarzyszy temu również względnie mała powierzchnia terenu, nie ma miejsca na kilka basenów, kilka barów i restauracji, z których turyści mogliby skorzystać, alejek i powierzchni zielonej. Stąd też skargi na brak drzew i krzewów, budowanie „betonowych twierdz”, które wymuszają skupienie wszystkich przyjezdnych na małej powierzchni. Wiele wind i traktów pionowych w godzinach posiłków jest niewydolnych, nie ma miejsc, w których turyści nie spotykaliby innych osób. Bary, których zazwyczaj jest kilka, są pełne, trudno znaleźć wolny stolik lub miejsce, po napój trzeba stać w kolejce. Wydłużone godziny podawania posiłków są pewnym rozwiązaniem, jeśli chodzi o minimalizację tłoku w restauracji, ale zmuszają wypoczywających do dostosowywania się do zachowań innych (na przykład przychodzenia na wczesną godzinę na śniadanie) lub też oczekiwania na wolny stolik. Podstawowe atrakcje hotelu, jakimi są na przykład baseny czy też bary, nie oferują klientom adekwatnej do ich liczby miejsc i przestrzeni - stąd też baseny, które nie dają turystom możliwości swobody w wodzie (zdaje się to odzwierciedlać określenie jednego z internautów: „pingwinowo”), leżaki ustawione blisko siebie, kolejki do napoi.

\subsection{Lokalizacja i otoczenie hotelu}

Oferty biur podróży określają lokalizację hotelu oraz jego odległość od lotniska. Teoretycznie goście wiedzą, że po przylocie będą musieli spędzić jeszcze jakiś czas $\mathrm{w}$ autobusie, który dowiezie ich na miejsce zakwaterowania. Ta wiedza nie zapobiega jednak pojawianiu się negatywnych komentarzy. Są one jeszcze bardziej emocjonalne, kiedy turyści uświadamiają sobie że przejechanie odległości 100 kilometrów może trwać trzy lub cztery godziny, gdyż poza rozwożeniem gości do poszczególnych hoteli na trasie specyficzną atrakcją jest postój w partnerskim zajeździe. Śladowo pojawiają się komentarze na temat odległości hotelu od innych atrakcji, miejscowości lub miasta. Możemy to interpretować przez pryzmat oczekiwań, jakie mają turyści pięciogwiazdkowych destynacji pobytowych: obiekt ma im zapewnić taką obsługę, że poszukiwanie atrakcji poza nim jest bezzasadne. Wydaje się jednak, że to nie jedyny powód. Jak już wskazywano, wybrzeże Turcji dysponuje rozbudowanym transportem publicznym, praktycznie wszędzie, gdzie pojawiają się obiekty hotelowe, pojawiają się dolmusze pozwalające dotrzeć turystom do najbliższych atrakcji. Kwestia "hoteli na pustyni”, czyli obiektów stojących na uboczu, praktycznie nie pojawia się ze względu na rozbudowującą się sieć hotelarską. Istnieją obiekty oddalone od komunikacji publicznej lub niemające do niej dostępu, niemniej w przypadku dużej części hoteli o najwyższym standardzie 
oferowane są bezpłatne busy do najbliższych miejscowości względnie na terenie hotelu można także usługę wykupić lub wezwać autoryzowane przez hotel taxi. Dlatego kwestia odległości od miejscowości pojawia się marginalnie.

Jako wada jawi się niekiedy najbliższe otoczenie hotelu — podstawę krytycznej oceny tworzy przyleganie/widok na teren budowy innych obiektów. W okresie sezonu turystycznego jest to jedynie kwestia estetyczna (ze względu na zakaz prowadzenia prac budowlanych), dlatego niektórzy goście skarżą się na nieatrakcyjny widok z pokoju czy też korzystają z oferowanego przez hotel dojazdu na plażę, gdyż spacer jest nieatrakcyjny. Czynnikiem, który może negatywnie wpływać na ocenę pobytu, może być także bliskie sąsiedztwo innych hoteli. Ścisła zabudowa obiektów hotelowych stawianych na stosunkowo małych działkach budowlanych $\mathrm{w}$ danym rejonie ma też inne konsekwencje, na które zwracają uwagę goście. Wieczorne pokazy i koncerty, animacje i dyskoteki oraz głośna muzyka przy basenie w sytuacji małej odległości przestrzennej poszczególnych obiektów sprowadza się do tego, że hotele podejmują swoistą „rywalizację dźwiękową", przez co wypoczywający nie są w stanie znaleźć cichych miejsc.

\subsection{Wyżywienie i realizacja opcji all inclusive}

Samo wyżywienie - mimo że internauci oceniają najwyżej klasyfikowane obiekty - także potrafi być źródłem rozczarowania gości. Słabością - wynikającą z wielkości obiektów i dysponowania tylko jedną restauracją główną - jest sama dostępność miejsca, w którym można spożyć posiłek. Właściciele obiektów tworzą wprawdzie zazwyczaj kilka miejsc spożywania posiłku (dwa poziomy, taras), ale to powoduje uciążliwe krążenie po części jadalnej w poszukiwaniu wolnego (i już uprzątniętego!) stolika. Poza tym większość potraw zlokalizowana jest w jednym miejscu, co powoduje kolejki. Dodatkową dysfunkcją, na którą zwracają uwagę wczasowicze, jest dostępność określonych potraw (na przykład pizzy, dań z grilla, tortów, owoców). Niekiedy takie potrawy są podawane na początku posiłku, a potem donoszone są jako ekwiwalentne tylko te, które cieszą się mniejszym powodzeniem. Stosunkowo rzadko krytykowane jest także wyżywienie jako całość - najczęstszym zarzutem w tym wymiarze jest monotonność i powtarzalność potraw przez cały pobyt. Jak wskazują niektórzy internauci, „nikt głodny nie chodzi”, ale smak potraw, ich wybór, tylko pozorne zróżnicowanie czy nieumiejętne przygotowanie potraw Zachodu (usmażone frytki podawane zanurzone w wodzie) są negatywnym wymiarem zakupionej oferty. Niekiedy krytyce poddaje się godziny posiłków, które są nieadekwatne dla wakacyjnego rytmu turystów (śniadanie kończące się o 9.30 i brak tak zwanego późnego śniadania, kolacja trwająca do 21.00). Sama opcja all inclusive również pada ofiarą krytyki. W przypadku napojów bezalkoholowych pojawia się kwestia niedostarczania do pokoju napojów i wody (mimo że w wielu ofertach są one standardem), dostępności soków, które są przygotowywane na bazie słodkich i syntetycznych koncentratów, zbyt małej 
liczby dystrybutorów z napojami, smaku i jakości kawy, braku wyboru herbat. Jeszcze więcej krytycznych opinii dotyczy napojów alkoholowych. Klienci hoteli o najwyższym standardzie oczekują alkoholi importowanych - a nie zawsze je otrzymują, dłuższego czasu wydawania bezpłatnych drinków - a to niekiedy jest realizowane tylko do 22.00, różnorodnych drinków - niektóre hotele w ramach opcji all inclusive oferują tylko wybrane typy. Bardzo często w recenzjach poszczególnych obiektów pojawia się kwestia stężenia alkoholu w napojach alkoholowych. Turyści zadowoleni z pobytu w obiekcie piszą, że alkohole są „uczciwe”, ci, którzy ten wymiar oceniają niżej, wskazują, że napoje są „rozwodnione” lub „chrzczone” czy „oszukane”.

\subsection{Pokoje}

Klient, wykupując usługę w hotelu pięciogwiazdkowym, powinien mieć zagwarantowany również pokój adekwatny do standardu obiektu. $Z$ tym bywa jednak różnie. Pomijając kwestię indywidualnych preferencji turystów (pokoje „ciche" vs. pokoje z widokiem na amfiteatr/basen), w obrębie niektórych obiektów istnieją pokoje lepsze i gorsze, o czym turyści skrupulatnie informują na forum. Pokój może mieć widok na nieużytki lub budowę obok, jego okna mogą sąsiadować $\mathrm{z}$ innym hotelem. Może być zlokalizowany w miejscu, które naraża turystę na nieprzyjemne zapachy $\mathrm{z}$ kanalizacji, wreszcie - co powtarza się w komentarzach najczęściej — od jego remontu mógł upłynąć długi czas. Szczególnej krytyce poddawane są łazienki - w niektórych są zacieki, w innych z kanalizacji wydobywa się nieprzyjemny zapach. Czasami ściany między pokojami pozwalają poznać zwyczaje codzienne sąsiadów, co jest negatywnie oceniane przez internautów.

\subsection{Personel i jego praca}

Goście w hotelu o wysokim standardzie oczekują profesjonalizmu obsługi, a osoby pracujące w hotelu mają być przyjazne. Turyści chcą być gośćmi, nie zaś uciążliwymi petentami. $Z$ wypowiedzi internautów wynika jednak, że niekiedy relacje z obsługą rzutują negatywnie na ocenę wypoczynku. Niektóre z hoteli odwiedzanych przez Polaków swoją ofertę kierują głównie do rosyjskich biur podróży i turystów byłego ZSRR, co jest odzwierciedlone w liczebności poszczególnych nacji i przekłada się na języki, którymi włada personel. Stąd też w wypowiedziach internautów pojawia się krytyka poziomu znajomości języka angielskiego przez osoby zatrudnione w hotelu, nawet te, które powinny go znać ze względu na wykonywane zadania (recepcja). Cechą cenioną przez turystów jest zaangażowanie personelu w pracę, z wpisów wynika, że nie w każdym hotelu mogą na to liczyć. Personel restauracji powolnie sprząta stoliki, nie proponuje gościom napoi, pod koniec posiłku stoi i uporczywie patrzy na jedzące osoby. Pół godziny przed zakończeniem obiadu lub kolacji nie dokłada się już niektórych potraw, mało 
tego - znikają poszczególne patery. Personel recepcji załatwia sprawy opieszale, zmiana pokoju w sytuacji, kiedy są inne wolne miejsca, wiąże się z wieloma wizytami i odkładaniem sprawy na późnej. Skonfigurowanie sejfu przez pracownika hotelu po wykupieniu płatnej usługi trwa dwa dni, a osoba sprzątająca pokój zapomina przynieść czyste ręczniki, po które trzeba samemu udać się do recepcji. To tylko niektóre z zachowań personelu, które przytaczają internauci.

\subsection{Usługi w obiekcie}

Hotele pięciogwiazdkowe zobligowane są do tego, aby oferować swoim gościom usługi ponadstandardowe. To zarówno opieka nad dziećmi, jak i hotelowa pralnia, internet i centrum konferencyjne, dyskoteka i animacje, mniej lub bardziej rozbudowany pakiet usług SPA, siłownia, rozmaite formy aktywności sportowej i rekreacyjnej. Na terenie obiektu jest zazwyczaj lekarz, sklep lub sklepy z pamiątkami, biżuterią itp., fotograf, czy fryzjer. Wśród wpisów internautów te kwestie pojawiają się jednak raczej sporadycznie.

Część turystów oczekuje od hotelu animacji, ich oceny niekiedy bywają negatywne. Ponieważ Polacy są w obiektach mniejszością, więc animacje adresowane są do tych nacji, których jest więcej - najczęściej Rosjan i Niemców. Krytyce poddaje się zatem język animacji oraz że oferowane występy i zabawy czy też puszczana muzyka odzwierciedlają gusty sąsiadów Polski, nie samych Polaków. Animatorzy powinni być zaangażowani w pracę i kreatywni i z tego powodu krytykowane są powtarzające się programy. Negatywnie oceniany jest również krótki czas wieczornych animacji (szczególnie tych adresowanych do dzieci). W dużych obiektach funkcjonuje odpowiednik przedszkola - klub dziecięcy. O ile sama idea krytykowana nie jest, o tyle z realiami jest już inaczej — pojawiają się skargi na to, że jedyną rozrywką, na którą mogą liczyć juniorzy, jest rysowanie kredkami. Tu istotny jest także mniejszościowy status gości — osoby opiekujące się dziećmi nie znają języka polskiego i dlatego niechętnie opiekują się dziećmi turystów z Polski.

\subsection{Baseny}

Basen czy baseny stanowią niewątpliwą atrakcję hotelową, stąd też bardzo duże zainteresowanie nimi oraz oceny tego aspektu infrastruktury hotelowej dokonywane w większości recenzji. Na pierwszym planie sytuuje się dostępność leżaków i parasoli. Konieczność „wstawania o 6 rano" i rezerwacji miejsc wypoczynku przez niektórych turystów są opisywane w opiniach z oburzeniem, inni starają się tłumaczyć sytuację szczytem sezonu i dużą liczbą turystów. Zaletą jest czysty i zadbany basen, $\mathrm{z}$ uważnym ratownikiem, obsługa, która ekspresowo sprząta - lecz nie zawsze tak się zdarza. Z tego wynikają zastrzeżenia do czystości wody i samego otoczenia, pracy ratowników i ich koncentracji na bezpieczeństwie 
gości, ale także niepodejmowania interwencji w sytuacji, kiedy goście łamią regulamin (zabawy na zjeżdżalniach, korzystanie $\mathrm{w}$ basenie $\mathrm{z}$ materacy i innego sprzętu tego typu) i utrudniają korzystanie z basenu innym. Niekiedy krytykowana jest głośna muzyka przy basenie - tak dzieje się, gdy na terenie obiektu jest tylko jeden basen, względnie przez turystów poddawany krytyce jest dobór repertuaru (powtarzalność, muzyka, która podoba się DJ-owi, a nie gościom). To, co podoba się jednym gościom, dla innych może stanowić podstawę krytyki. Egzemplifikacją może być duży basen przy jednym z hoteli, którego głębokość zaczynała się od 1,6 metra. Dodatkowo restrykcyjnie egzekwowany regulamin basenu nie pozwalał na używanie w nim materacy dmuchanych itp., co sprawiało, że mogły z niego korzystać jedynie osoby umiejące pływać. Finalnie część turystów wskazywała, że jest to najsilniejsza strona hotelu, gdyż mogli bez ograniczeń, tłoku i kolizji pływać, a część krytykowała hotel ze względu na niemożność korzystania z niego.

\subsection{Plaża}

Własna plaża (ewentualnie wydzielona część plaży publicznej) jest standardem najwyżej skategoryzowanych hoteli. Jednak ze względu na usytuowanie atrakcyjność tego elementu nabytej oferty w rzeczywistości jest zróżnicowana. Dysfunkcją nie jest odległość hotelu od plaży i dojście lub dojazd do niej, ale sama plaża, jej ukształtowanie, wielkość, podłoże oraz utrzymanie. Krytykowane jest to, że plaża jest wąska, co wiąże się także z małą liczbą dostępnych leżaków i przestrzeni hotelowej. Podobnie jak w przypadku rezerwowania miejsc przy basenie - zmusza to turystów do wczesnego wstawania. Plaża w folderze turystycznym opisana jako piaskowo-żwirkowa może okazać się plażą kamienistą, na której wejście do wody możliwe jest tylko z pomostu. Sam pomost jako uzupełnienie szerokiej i piaszczystej plaży jest atrakcją. Przestaje nią być, jeśli to jedyna możliwość wypoczynku turysty nad wodą i zejścia do niej. Wpływ hotelu na warunki środowiskowe jest dość ograniczony, niemniej są w tym zakresie pewne możliwości sprawstwa. Turyści jednego z hoteli wskazują, że na samym początku jego działalności obiekt dysponował plażą piaszczystą, gdyż na nadbrzeże nawieziono piasek. Z czasem został on wypłukany, ale hotelarz zadowolony z pozytywnych opinii i zdjęć dawnej plaży w folderach nie podjął działań naprawczych. Kwestią, która pozostaje w gestii właściciela i kierownictwa obiektu, jest jednak czystość. W wypowiedziach na forum krytykowana jest także jakość sprzątania terenu będącego w dyspozycji gości. Niekiedy turyści starają się tłumaczyć pracowników hotelu tym, że w trakcie użytkowania plaży goście brudzą, kiedy indziej turyści są bardziej radykalni i oczekują szybkiej reakcji nawet w czasie odpoczynku. 


\section{Zakończenie}

Otwarcie granic, „rozbudowa” rynku usług turystycznych, tanie i efektywne środki komunikowania, sytuacja materialna - to tylko niektóre z czynników, które sprawiają, że część Polaków wyjeżdża za granicę w celach turystycznych i wypoczynkowych. Bogata oferta biur podróży, wygoda, kiedy indziej cena całościowej usługi w sezonie, tworzą determinantę wyjazdów zapośredniczonych przez touroperatorów. W przypadku takich wyjazdów Turcja od wielu lat jest krajem bardzo atrakcyjnym. Zagrożenie terroryzmem i obawy co do stabilności politycznej państwa sprawiają, że w pewnych okresach liczba turystów spada, niemniej kiedy powyższe kwestie przestają zagrażać wizytującym, Turcja powraca do grona krajów najchętniej odwiedzanych. Turyści wybierający najwyższy standard hoteli cenią ich rozbudowaną infrastrukturę, dostępność rozmaitych usług. Zwracają uwagę na bardzo zróżnicowane wyżywienie i możliwość skorzystania z oferty all inclusive w każdym momencie. Lubią piaszczyste plaże, rozbudowane kompleksy basenowe, zieleń i przestrzeń społeczną. Zaletą jest dla nich zaangażowana i sprawna obsługa, orientacja na turystę-klienta, błyskawiczne reagowanie na jego prośby i sugestie. Decyzje podejmowane przez konsumentów teoretycznie zapadają po zapoznaniu się z ofertą. Nie krytykują oni zatem kwestii, które były w niej już wskazane (odległość od plaży, ograniczenia opcji all inclusive itp.), ale krytyce poddają to, co w tej ofercie finalnie uwzględnione nie było. Stąd też nie wszyscy konsumenci usług hotelowych trafiają $\mathrm{w}$ idealne miejsca, realizacja ich początkowych wyobrażeń w praktyce wyraźnie odbiega od oczekiwań. $\mathrm{Z}$ tego względu w wypowiedziach internautów opisywane są obiekty o najwyższej standaryzacji, które nie dają możliwości zaznania spokoju i oczekiwanego wypoczynku, nakładają konieczność obcowania z innymi, wypracowywania codziennych strategii dostosowawczych w pozyskiwaniu cenionych dóbr. Te hotele - gdyby ich kierownictwo było tym zainteresowane - mogłyby z powodzeniem usunąć lub zminimalizować część niedogodności, niemniej pytaniem otwartym pozostaje kwestia woli przedsiębiorców.

Jeśli chodzi o samą Turcję i jej turystykę, to kraj planuje rozwój oferty oraz zainteresowanie przyjazdem turystów dotąd ją śladowo odwiedzających. O ile europejscy turyści są nadal istotni, o tyle kluczowe w przyszłości stanie się pozyskanie turystów z Dalekiego Wschodu, zwiększenie napływu turystów z Chin, orientacja na klientów z Indii ${ }^{80}$ oraz zwiększenie zainteresowania turystyką medyczną ${ }^{81}$. Rok 2018 z perspektywy liczby przybywających osób był korzystny, nawet bardzo korzystny - od stycznia do sierpnia 2018 roku do Turcji przyjechało 27 milionów gości, o $22,9 \%$ więcej niż w analogicznym okresie poprzedniego roku ${ }^{82}$. Zyski

${ }^{80}$ M. German, Turecka branża...

81 M. German, 100 procent...

82 M. German, Antalya pobiła własny rekord w turystach, 9.10.2018, https://www.rp.pl/ Obyczaje/310099972-Antalya-pobila-wlasny-rekord-w-turystach.html (dostęp: 15.10.2018). 
z turystyki są jednak mniejsze, gdyż podpisywane umowy mogły być bardziej korzystne dla kraju i jego hotelarzy. Z tego może wyniknąć sytuacja wzrostu cen, co w przypadku turystów z Polski może okazać się pewnym ograniczeniem, jeśli chodzi o ich decyzje zakupowe, a dodatkowym katalizatorem mogą być tutaj decyzje rynkowe innych konsumentów ${ }^{83}$.

\section{Bibliografia}

Adamczyk A., Quo vadis Turcjo - koniec europejskiego kierunku w polityce zagranicznej Turcji, „Rocznik Integracji Europejskiej” 2017, nr 11, s. 29-43.

Adamczyk A., Znaczenie konstytucji tureckiej z 1961 roku dla rozwoju idei państwa prawnego w Turcji, „Zeszyty Prawnicze UKSW” 11, 2011, nr 3, s. 33-61.

Alejziak W., Globalna polityka turystyczna - utopia, alternatywa czy konieczność?, „Folia Turistica” 25, 2011, nr 2. Wydanie specjalne z okazji 35-lecia Wydziału Turystyki i Rekreacji AWF w Krakowie, „Z warsztatów mistrzów”, red. W. Alejziak, s. 343-380.

Berbeka J., Konsumpcja usług turystyki społecznej - obecnie i w przyszłości, „Konsumpcja i Rozwój” 2014, nr 2, s. 39-49.

Berbeka J., Zachowania polskich konsumentów na rynku usług turystycznych, [w:] Zachowania konsumentów na rynku dóbr i usług, red. I. Ozimek, Warszawa 2010, s. 84-102.

Bieniek K., Ewolucja pozycji ustrojowej władzy wykonawczej w Republice Turcji, „Białostockie Studia Prawnicze" 2016, nr 20/B, s. 395-405, https://repozytorium.uwb.edu.pl/jspui/bitstream/11320/4594/1/BSP_20B_Bieniek.pdf (dostęp: 10.10.2018).

Cohen E., Zmieniające się oblicza współczesnej turystyki, „Folia Turistica” 25, 2011, nr 2. Wydanie specjalne z okazji 35-lecia Wydziału Turystyki i Rekreacji AWF w Krakowie, „Z warsztatów mistrzów”, red. W. Alejziak, s. 13-20.

Cymański W.J., Czas wolny, turystyka i rekreacja w perspektywie socjologicznej, Kraków 2017.

Dejnaka A. et al., Działalność informacyjna członków gospodarstwa domowego i jego decyzje ekonomiczne, Warszawa 2012.

„Folia Turistica” 25, 2011, nr 2, Wydanie specjalne z okazji 35-lecia Wydziału Turystyki i Rekreacji AWF w Krakowie, „Z warsztatów mistrzów”.

German M., 100 procent Polakóww Turcji więcej,25.05.2018, https://www.rp.pl/Obyczaje/305259996100-procent-Polakow-w-Turcji-wiecej.html (dostęp: 2.08.2018).

German M., Antalya pobiła własny rekord w turystach, 9.10.2018, https://www.rp.pl/Obyczaje/310099972-Antalya-pobila-wlasny-rekord-w-turystach.html (dostęp: 15.10.2018).

German M., Hiszpania traci na niskich cenach Turcji, 5.07.2018, https://www.rp.pl/Hotele/307059968Hiszpania-traci-na-niskich-cenach-Turcji.html (dostęp: 2.08.2018).

German M., Hotele w Alanyi obłożone w 100 procentach, 17.08.2018, https://www.rp.pl/Obyczaje/308179978-Hotele-w-Alanyi-oblozone-w-100-procentach.html (dostęp: 1.10.2018).

German M., Niemcy podróżują etycznie, 19.06.2018, https://www.rp.pl/Obyczaje/180619268-Niemcy-podrozuja-etycznie.html (dostęp: 1.10.2018).

German M., Turecka branża turystyczna zadowolona z ruchu turystów, 22.08.2018, https://www.rp.pl/ Obyczaje/308229997-Turecka-branza-turystyczna-zadowolona-z-ruchu-turystow.html (dostęp: 22.08.2018).

German M., Tureckiehotele prawie wyprzedane,16.07.2018,https://www.rp.pl/Biura-podrozy/307169977Tureckie-hotele-prawie-wyprzedane.html (dostęp: 2.08.2018).

83 M. German, Za rok Niemcy znów wybiora Turcję, 17.10.2018, https://www.rp.pl/Biurapodrozy/310179998-Za-rok-Niemcy-znow-wybiora-Turcje.html (dostęp: 30.10.2018). 
German M., W Niemczech sprzedaż Turcji rośnie dwucyfrowo, 13.09.2018, https://www.rp.pl/Biura-podrozy/309139984-W-Niemczech-sprzedaz-Turcji-rosnie-dwucyfrowo.html (dostęp: 2.10.2018).

German M., Za rok Niemcy znów wybiora Turcje, 17.10.2018, https://www.rp.pl/Biura-podrozy/310179998-Za-rok-Niemcy-znow-wybiora-Turcje.html (dostęp: 30.10.2018).

Gersz A., Turcja. Trwaja represje po nieudanym puczu. Aresztowano tysiace wojskowych, sędziów i urzędników, 18.07.2016, https://polskatimes.pl/turcja-trwaja-represje-po-nieudanym-puczu-aresztowano-tysiace-wojskowych-sedziow-i-urzednikow/ar/10419184 (dostęp: 1.10.2018).

Godfrey K., Turkey holiday travel advice: Latest update as terror attacks 'very likely', 5.06.2018, https://www.express.co.uk/travel/articles/969707/turkey-holiday-flights-travel-advice-terror-attacks-latest-news-istanbul-ankara/amp (dostęp: 30.09.2018).

http://www.pzot.pl/index.php?module=cms/files\&group=Raporty\%20PZOT (dostęp: 10.10.2018).

Kaczmarek J., Stasiak A., Włodarczyk B., Produkt turystyczny: pomyst, organizacja, zarządzanie, Warszawa 2005.

Konsumpcja jako forma komunikacji społecznej. Nowe paradygmaty i konteksty badawcze, „Prace Naukowe Uniwersytetu Ekonomicznego we Wrocławiu” 2015, nr 414, red. W. Patrzałek.

Kulturowe determinanty zachowań konsumenckich, red. W. Patrzałek, Wrocław 2004.

Middelton V.T.C., Marketing w turystce, Warszawa 1996.

Milian L., Socjologia czasu wolnego. Wiedza o czynnościach swobodnie wybieranych, Gdańsk 2010.

Niemczyk A., Zróżnicowanie zachowań konsumentów na rynku turystyki kulturowej, Kraków 2012.

Patrzałek W., Czynniki kulturowe wplywajace na zachowania konsumentów, [w:] Kulturowe determinanty zachowań konsumenckich, red. W. Patrzałek, Wrocław 2004, s. 11-37.

Perchla-Włosik A., Wardzała J., Wybrane zachowania młodzieży realizowane $w$ sferze konsumpcji w świetle badań własnych, [w:] Wspótczesna teoria i praktyka badań społecznych i humanistycznych. Ksiega Jubileuszowa Wydziału Nauk Społecznych, red. J. Juchnowski, R. Wiszniowski, Toruń 2013, s. 704-720.

Perchla-Włosik A., Współczesny konsumpcjonizm, [w:] Kulturowe determinanty zachowań konsumenckich, red. W. Patrzałek, Wrocław 2004, s. 38-52.

Podemski K., Polski turysta za granica. Od stalinizmu do Schengen i Wizz Air, „Folia Turistica” 25, 2011, nr 2, Wydanie specjalne z okazji 35-lecia Wydziału Turystyki i Rekreacji AWF w Krakowie, „Z warsztatów mistrzów”, red. W. Alejziak, s. 235-255.

Polska Izba Turystyki, Zagraniczne wakacje Polaków 2017, Warszawa 2017.

Polska Izba Turystyki, Zagraniczne wakacje Polaków 2018, Konferencja prasowa Polskiej Izby Turysty$k i$, Warszawa, 6.09.2018, http://www.pit.org.pl/media/1/002/009/2129.pdf (dostęp: 20.09.2018).

Polski Związek Organizatorów Turystyki, Polish Tourism 2015/16 from the perspective of Polish Tour Operators Association \& MerlinX, http://www.pzot.pl/tempOpen/default/files/00000003GBVM HLU573G5WUFGS472TCH3_Turism2016_17_PZOT_MerlinX.pdf (dostęp: 9.11.2016).

Polski Związek Organizatorów Turystyki, Weekly Report 20/2018, 22.05.2018, http://www.pzot. pl/tempOpen/default/files/000000025R737YPYGZW2XG40RYAOE51C_Booking_Report_20_2018.pdf (dostęp: 10.10.2018).

Położenie i warunki naturalne Turcji, 2.12.2016, http://www.wirtualnaturcja.pl/turcja-geografia/polozenie-i-warunki-naturalne-turcji.html (dostęp: 15.09.2018).

Power G., The UK Foreign Office says the country is 'generally safe' as it starts to rebuild its tourism sector, 24.07.2018, http://www.theweek.co.uk/turkey/93371/how-safe-is-it-to-travel-to-turkey-in-2018 (dostęp: 30.09.2018).

Przecławski K., Człowiek a turysta. Zarys socjologii turystyki, Kraków 1996.

Sala K., Postmodernistyczne zachowania konsumentów na rynku turystycznym w Polsce, Kraków 2018.

Sikora J., Teoretyczno-empiryczne aspekty związków potrzeb, popytu i konsumpcji w turystyce, „Zeszyty Naukowe Uniwersytetu Szczecińskiego. Ekonomiczne Problemy Usług” 2012, nr 82, s. 125-137.

Sokołowski J., Wpływ ataków terrorystycznych na popyt i podaż w usługach turystycznych, „Prace Naukowe Uniwersytetu Ekonomicznego we Wrocławiu" 2017, nr 487, s. 284-292. 
Szkudlarek M., Od Atatürka do Erdoğana - ewolucja roli religii w Turcji w okresie rządów AKP, „Refleksje” 2014, nr 9, s. 50-69.

Turcja - koniec stanu wyjątkowego, Polskie Radio, 19.07.2018, https://www.rp.pl/Rozmaitosci/307199963-Turcja---koniec-stanu-wyjatkowego.html (dostęp: 1.10.2018).

Turcja — ostrzeżenie dla podróżujacych, Komunikat Ministerstwa Spraw Zagranicznych, 29.08.2018, https://msz.gov.pl/pl/informacje_konsularne/ostrzezenia/turcja_ostrzezenie_dla_podrozujacych_1 (dostęp: 1.10.2018).

Turcja: 16 milionów turystów, a rok jeszcze trwa, 7.11.2017, http://turystyka.rp.pl/artykul/1344152. html? referer=redpol (dostęp: 8.11.2018).

Turecka turystyka liczy na pół miliona Polaków, 18.12.2017, http://turystyka.rp.pl/artykul/1349321. html? referer=redpol (dostęp: 10.09.2018).

Urbaniak A., Neoosmanizm. Polityka zagraniczna Turcji okresu rzadów partii Sprawiedliwości i Rozwoju (AKP), „Edukacja Humanistyczna” 31, 2014, nr 2, s. 29-44.

Wardzała J., Zmiany w postrzeganiu roli młodzieży we wspótczesnym społeczeństwie konsumpcyjnym, [w:] Konsumpcja jako forma komunikacji społecznej. Nowe paradygmaty i konteksty badawcze, „Prace Naukowe Uniwersytetu Ekonomicznego we Wrocławiu” 2015, nr 414, red. W. Patrzałek, s. 250-258.

Wardzała-Kordyś J., Opinie o produktach wadliwych i aktywność reklamacyjna gospodarstw domowych [w:] A. Dejnaka et al., Działalność informacyjna członków gospodarstwa domowego i jego decyzje ekonomiczne, Warszawa 2012, s. 175-181.

Wasilewski K., Turcja w okresie przemian: wnioski dla strategii UE, Warszawa 2017.

Wasilewski K., Turecki sen o Europie - tożsamość zachodnia i jej wplyw na politykę zagraniczna republiki Turcji, Warszawa 2015, http://wnpism.uw.edu.pl/media/SOBN/Archiwum\%20WDiNP/ Turecki\%20sen\%20o\%20Europie.pdf (dostęp: 10.10.2018).

Wolska A., Trendy w konsumpcji turystycznej na przykładzie mieszkańców Majorki, „Prace Naukowe Uniwersytetu Ekonomicznego we Wrocławiu" 2015, nr 379, s. 356-365.

Współczesna teoria i praktyka badań społecznych i humanistycznych. Ksiegga Jubileuszowa Wydziału Nauk Społecznych, red. J. Juchnowski, R. Wiszniowski, Toruń 2013.

Wyjazdy wypoczynkowe Polaków w 2013 roku i plany na rok 2014, „Komunikat z Badań CBOS” nr 25/2014, Warszawa, luty 2014.

Wyjazdy wypoczynkowe Polaków w 2014 roku i plany na rok 2015, „Komunikat z Badań CBOS” nr 16/2015, Warszawa, luty 2015.

Wyjazdy wypoczynkowe Polaków w 2015 roku i plany na rok 2016, „Komunikat z Badań CBOS” nr 21/2016, Warszawa, luty 2016.

Wyjazdy wypoczynkowe Polaków w 2016 roku i plany na rok 2017, „Komunikat z Badań CBOS” nr 24/2017, Warszawa, luty 2017.

Wyjazdy wypoczynkowe Polaków w 2017 roku i plany na rok 2018, „Komunikat z Badań CBOS” nr 28/2018, Warszawa, luty 2018.

Zagraniczne wakacje Polaków 2018, https://www.travelplanet.pl/blog/zagraniczne-wakacje-polakow-2018-raport-polskiej-izby-turystyki/ (dostęp: 10.10.2018).

Zakrzewska J., Potencjał kulturowy Turcji a preferencje turystyczne Polaków i dostępność kulturowej oferty turystycznej, „Turystyka kulturowa” 2010, nr 12, s. 17-34.

Zarządzanie kryzysem związanym z uchodźcami: Komisja składa sprawozdania z realizacji wspólnego planu działania UE-Turcja, Komunikat prasowy Komisji Europejskiej, Bruksela 10.02.2016, europa.eu/rapid/press-release_IP-16-268_pl.pdf.

Zobacz na mapie: Turcja celem zamachowców, 1.01.2017, https://www.polityka.pl/tygodnikpolityka/ swiat/1688974,1,zobacz-na-mapie-turcja-celem-zamachowcow.read (dostęp: 30.09.2018). 


\section{The attractiveness of hotels in the perception of buyers of tourist services: The example of Turkey}

\section{Summary}

The emergence of leisure time, as well as transformational changes taking place in Poland, meant that Polish tourists could start travelling to other countries for tourism. This article attempts to answer questions about what constitutes a high standard for visitors leaving, which is associated with their disappointment with the purchased offer. These issues were related to the country which for years was eagerly visited by tourists from Poland, and in 2018 returned to the top of the ranking of preferred destinations - Turkey. Research based on secondary data analysis has allowed the author to look at issues that have an impact on the tourist attractiveness of a given country, but first and foremost, it has made it possible to decode factors that are important to travelers and which are less important during a leisure stay. 